\title{
Re-assessment of the near-endemic taxa in the Egyptian Flora
}

\author{
Shaltout K.', Ahmed D. ${ }^{1}$, Diab M.² and El-Khalafy M.2*
}

'Botany Department, Faculty of Science, Tanta University

${ }^{2}$ Botany Department, Faculty of Science, Kafr El-Sheikh University.

*Corresponding author: Dr.MohamedElkhalafy@yahoo.com

\begin{abstract}
This paper aims to answer the following questions: 1- what is the actual number of near-endemic taxa in the Egyptian flora?, 2- what are the reasons and justifications for addition or exclusion of plants to or from the final list of near-endemic taxa?, 3- what are the conservation categories of near-endemic taxa according to IUCN?, 4- How can we make a red list of these taxa?, 5-what are the services and goods offered by near-endemic taxa?, and 6- what are the threats that impact these taxa most?. These aims are achieved through preparing a recent list for the near-endemic taxa and their habitats in the Egyptian flora. The lists were analyzed in terms of taxonomic diversity, life and sex forms, size structure, flowering activity, dispersal types, economic potential, threats and national floristic distribution, and IUCN categories. The total number of near-endemic taxa in the prepared recent list is 73, belonging to 58 genera and 28 families; and were recorded in 11 habitats. The life form represented most is the therophytes while the ballochores and pogonochores are the most represented dispersal types. There was a gradual increase in the frequency of the flowered taxa until reaching a maximum value from March to May, and then decreased again reaching a minimum value from August to January. Near endemics are distributed in Egypt and adjacent countries as follows: 39 taxa with Palestine, 19 with Libya, 8 with Saudi Arabia, 4 with Sudan, 2 with Jordan, and only one with Lebanon. Fifty-one taxa had a distribution in only one phyto-geographical region, while the remaining taxa had a distribution in two or more regions. All near-endemic taxa have at least one aspect of economic goods and exposed to at least one type of threats, where the most represented good was the medicinal uses, while over-collecting and over-cutting were the most represented threats. In this paper, 30 near-endemics were evaluated according to IUCN categories as follows: 12 endangered, 5 critically endangered, 4 extinct and 1 vulnerable, while 8 species are data deficient. In addition, 36 near-endemics were also evaluated in previous studies according to IUCN categories as follows: 15 endangered, 11 critically endangered, 7 vulnerable, 2 rare and 1 least concern.
\end{abstract}

Key words: Endemism, Egyptian Flora, Near-endemics, Biodiversity, Conservation, IUCN categories.

\section{Introduction}

From a bio-geographical view point, endemism is the restriction of the natural range of a taxon to a defined geographical distribution or habitat type (Anderson 1994 and Gaston 1994); with either political boundaries of a country (endemics), or ecogeographical boundaries of two or more countries regardless of their political boundaries (near- endemics), however the narrow-distributed taxa are called stenoendemics (Gaston 1994) or steno- near endemics. Apart from the loss of natural habitats and climatic changes, the excessive human activities (e.g. over exploitation) may generally make endemics and near-endemics to become extinct taxa (Thomas et al. 2004). Also, some important natural threats were recorded such as the aridity of the area with very scarce precipitation year round (Thomas l.c.). Human impacts, animal grazing, and traditional plant collection for medicinal uses, further intensify the natural threats of aridity and fragmentation, thus pushing these taxa to the extinction (Zaghloul et al. 2006 and Mansour et al. 2013). In the recent centuries, the rate of extinction has been accelerated, causing hundreds or perhaps thousands of species, subspecies and varieties to become extinct every year (Cunningham and Cunningham 1997).

Egypt lies in the northeastern part of Africa and extends to Asia (Sinai Peninsula). According to Wickens (1992), Egypt is perhaps the most arid country in North Africa 


\section{Re-assessment of the near-endemic taxa in the Egyptian Flora}

in which desert conditions prevail throughout the country. Egypt contains four main geographical regions: Western Desert including the Mediterranean coastal belt $\left(681,000 \mathrm{~km}^{2}\right)$, Eastern Desert $\left(223,000 \mathrm{~km}^{2}\right)$, Nile Land $\left(25,000 \mathrm{~km}^{2}\right)$ and Sinai Peninsula $\left(61,000 \mathrm{~km}^{2}\right)$. The Nile Land includes several islands in the main stream of the River and its Delta branches. Fayium depression $\left(1700 \mathrm{~km}^{2}\right)$ is connected to the Nile region by a principal irrigation canal called Youssef Sea (Zahran and Willis 2009).

Boulos (2009) reported that the nearendemic taxa in Egypt are 93, while Hosni et al. (2013) reduced them to 61. Many studies have been carried out to provide a conservation assessment for different plant species. Although many conservation studies have taken place in Egypt for sometimes, yet there is a lack of comprehensive information on species distribution and recent IUCN categories (Hosni et al. 2013). IUCN (1998) listed 82 threatened species in Egypt of which two are extinct and 19 endangered. Following IUCN (1994) categories, El- Hadidi and Hosni (2000) provided a list of 457 threatened species in the Egyptian flora; however, most of these studies did not apply the appropriate criteria used to evaluate species conservation status (Hosni et al. 2013). Because of the continuing decline of plant diversity, many initiatives have developed over recent decades for conservation of the most threatened diversity (Mace et al. 2008, Jetz and Freckleton 2015 and Maes et al. 2015). The IUCN red list of threatened species is widely recognized as the most objective approach for evaluating the conservation status of species and categorizing them according to their estimated risk of extinction (e.g. Mace et al. 2008, Jetz and Freckleton 2015 and Maes et al. 2015). The IUCN red list uses criteria with quantitative thresholds based on population size, rate of decline, and area of distribution to assign species to categories of relative extinction risk, ranging from least concern, through near threatened, vulnerable, endangered and critically endangered to extinct in the wild and extinct (IUCN 2001). Traditionally, IUCN red list has served not only to highlight species at greatest risk of extinction, but also to guide conservation responses, primarily by identifying key and priority habitats for species, sites to be safeguarded, and actions required (Collar 19931994, 1996).

Near-endemics are considered as taxa restricted to Egypt and a neighboring country (Boulos 2009). They are important components in the flora of most regions of the world. Most of these species have become exposed to extinction within the last years as a result of a lot of reasons such as environmental conditions and human activities. Extinction of these species is considered as a major threat to biodiversity, therefore, there is an urgent need to study these species in the Egyptian flora and evaluate them according to IUCN categories, and to prepare conservation strategy for them. This paper aims at: 1 - preparing a recent list for the near-endemic species in the Egyptian flora, 2- reporting the reasons and justifications for addition or exclusion of plants to or from the final list of near-endemic species, 3determining the conservation categories of near-endemic taxa according to IUCN, 4preparing a red list of these taxa, 5- recording the services and goods offered by the nearendemics, and 6- determining threats that impact these taxa.

\section{Material and Methods}

Ten field visits were conducted during summer 2015 to spring 2018 to many locations allover Egypt including Saint-Catherine, Matrouh, Alexandria, Aswan and Assiut for collecting the near-endemic taxa in Egypt as live material or from herbaria. The available 


\section{Shaltout et al.}

information and data such as: main habitats, coordinates, uses and threats for taxa were recorded through visiting different sites. Other information was collected from the herbaria of Cairo University (CAI), Tanta University (TANE), Agriculture Museum (CAIM), Aswan University (ASW), Assiut University (ASTU) and Alexandria University (ALEX). In each location, specimens of plant taxa were collected from different sites, and seed samples representing the recorded taxa were also collected as can as possible. Other notifications were taken into account, if possible, such as sex form, size structure, life form, flowering time and dispersal type of diaspores. Other information was collected from the herbaria of Cairo University (CAI), Tanta University (TANE), Agriculture Museum (CAIM), Aswan University (ASW), Assiut University (ASTU) and Alexandria University (ALEX). Information from the available literature (papers, books, M. Sc. and Ph.D. Theses, and scientific reports) was also taken into consideration.

A recent checklist including 73 nearendemics arranged alphapitically according to LAPG III (The Linear Angiosperm Phylogeny group) system (Haston et al. 2009) and based on literature and database reviews. These resources include previous floras and available literature (Täckholm et al. 1941, Täckholm and Drar 1950, 1969, Andrews 1950- 1956, Townsed and Guest 1966- 1980, Zohary 1966, 1987, Davis et al. 1972-1982, Täckholm 1956,1974, Jafri and El-Gadi 1977-1988, Feinbrun-Dothan 1978, 1986, Collenette 1985,1999, Migahid 1988- 1990, Boulos 19992009, El-Hadidi and Hosni 2000, Ahmed 2009, Shaltout et al. 2010, and Ibrahim et al. 2016). The following websites were also consulted to collect more information about the recorded plants:
1- Euro +Med plant base (http://ww2.bgbm.org/EuroPlusMed/query.as p).

2- Kew world checklist of different plant families (http://wcsp.science.kew.org).

3- International Plant Name Index (IPNI; http://www.ipni.org).

4- The Plant List (http://www.theplantlist.org).

5- Plants of the World Online-Kew Science

(http://www.plantsoftheworldonline.org).

6- Catalogue of Life (http://www.catalogueoflife.org/annualchecklist/2010).

7Tropicos (http://www.tropicos.prg/Home.aspx).

8- Global Biodiversity Information Facility (GBIF; http://www.gbif.org/occurence).

9- African Plant database (http://www.villege.ch/musinfo/bd/cjb/africa).

10- JSTOR Global Plant Science (http://plants.jstore.org).

Following Boulos (2009), the nearendemic taxa are those restricted to Egypt and only an adjacent country. Identification of plant specimens was carried out depending on the previous mentioned literature. Some identifications were revised in TANE based on the available authentic materials. Voucher specimens were deposited in TANE and Kafr El-Sheikh University Herbaria. The phytogeographical regions of the studied species were recorded according to those proposed by Boulos (2009). Dispersal type of the recorded taxa was assessed using the system of Dansereau and Lems (1957), while life forms were assessed using the system of Raunkiaer (1937). A theoretical framework of an eightcelled table is proposed by Rabinowitz (1981) for the different types of rarity depending on range, habitat specificity and local abundance. 


\section{Re-assessment of the near-endemic taxa in the Egyptian Flora}

Assessment of the near-endemic taxa in Egypt included in the list prepared in the present study is based on IUCN categories (IUCN 2003). According to further revisions published by IUCN (2003), there are three principle categories for species at high risk of extinction: critically endangered, endangered and vulnerable. Species are assigned to a category if they meet the appropriate quantitative threshold for at least one of five criteria. There are four criteria which are based on the size and the rate of decline of the population and/ or geographical range, with the fifth related to quantitative models of extinction risk such as population viability analyses (Butchart et al. 2004). The evaluation process includes three steps: 1- previously prepared list by IUCN (1998) modified in 2013, 2014 and 2017 (Hosni et al. 2013, Omar 2014-2017); 2- previously prepared list by ElHadidi and Hosni (2000); and 3- the present list based on the recent data and the Geocat software (http://www.geocat.Kew.org). The present study depended on the criterion $B$ which is concerned with geographic range in the form of either extent of occurrence (EOO) or area of occupancy (AOO). Calculations of both $\mathrm{AOO}$ and EOO and assessment process were carried out using the Geocat software, with the appropriate category depending on the different coordinates of plants.

\section{Results}

The present list of near-endemic species in the Egyptian flora included 73 near-endemic taxa (73 species, 5 subspecies and 8 varieties) belonging to 58 genera and 28 families (Table 1). The most represented genera among the near-endemics are Bellevalia and Allium (4 taxa for each). Monocotyledons are represented by 12 species and 2 subspecies belonging to 7 genera and 6 families. The families represented most are Asparagaceae (6 taxa), followed by Amaryllidaceae (4 taxa). In addition, 22 dicotyledonous families are represented. The families represented most are Fabaceae, Asteraceae (8 taxa each), followed by Apiaceae, Scrophulariaceae (5 taxa each), and Lamiaceae (4 taxa). Near-endemic taxa are distributed in the neighboring countries as follows: 39 taxa with Palestine, 19 taxa with Libya, 8 taxa with Saudi Arabia, 4 taxa with Sudan, 2 taxa with Jordan and 1 taxon with Lebanon. The variation of the recorded taxa according to their habitats revealed that the rocky surfaces and sandy formations are the richest in terms of varieties, sub-species, species, and families (Table 2). The relation between the frequencies of the near- endemic taxa in the Egyptian flora in relation to the number of the habitats in which they occur approximates an inverse J-shape distribution (Fig. 1).

There is a gradual decrease of the taxa frequency with the increase of the number of habitats, starting with the taxa that occur in one habitat (44 taxa $=60.3 \%$ ), and ending with those in four habitats (only one taxon: Carduncellus mareoticus).

The determination of the life forms indicated that the therophytes are the most represented ( 24 taxa $=32.9 \%$ of the total taxa), followed by chamaephytes (20 taxa $=27.4 \%$ ) and hemicryptophytes (12 taxa $=16.4 \%)$ (Fig. 2). 


\section{Shaltout et al.}

Table. 1. Characteristics of the near-endemic taxa in the Egyptian Flora. The phytogeographical regions are abbreviated as follows: N: Nile region, O: Oases of the western desert, M: Mediterranean coastal region, D: All deserts of Egypt except that of Sinai, De: Desert east of the Nile, Dw: Desert west of the Nile, R: Red Sea region, GE: Gebel Elba region and S: Sinai Peninsula. The dispersal types are coded as follows: Bal: balochore, Pog: pogonochore, Des: desmochore, Pte: pterochore, Mic: microsclerochore and Sac: sarchochore. The life forms are coded as follows: GH; geophyte-helophyte, Ge: geophyte, Th: therophyte, Ch: chaemaphyte, Ph: phanerophyte and Hi: hemicryptophyte, *: refers to endemic plants transferred to near endemic plants in the present study. The habitats are coded as follows: BW: banks of water bodies, PDW: desert plains, depressions and wadis, SF: sandy formations, AL: alluvial soils, CF: cultivated fields, MH: mountains and hills, RF: rocky surfaces, WS: well sides, RS: roadsides, CG: calcerous ground and FW: Fallow fields and waste ground.

\begin{tabular}{|c|c|c|c|c|c|c|}
\hline Taxa & $\begin{array}{c}\text { Life } \\
\text { form }\end{array}$ & $\begin{array}{c}\text { Dispersal } \\
\text { type }\end{array}$ & $\begin{array}{l}\text { Geographic } \\
\text { distribution }\end{array}$ & $\begin{array}{c}\text { Neighboring } \\
\text { country }\end{array}$ & $\begin{array}{c}\text { Flowering } \\
\text { time }\end{array}$ & Habitat \\
\hline \multicolumn{7}{|l|}{ Amaranthaceae } \\
\hline $\begin{array}{l}\text { 1- Haloxylon negevensis (Iljin \& Zohary) } \\
\text { Boulos }\end{array}$ & $\mathrm{Hi}$ & Pog. & $\mathrm{S}$ & Palestine & Sep-Dec & $\mathrm{RF}$ \\
\hline 2- Anabsis syriaca Iljin var. syriaca & Ch & Pog. & $\mathrm{S}$ & Libya & Oct-Nov & RF, PDW \\
\hline \multicolumn{7}{|l|}{ Amaryllidaceae } \\
\hline 3- Allium barthianum Asch. \& Schweinf. & GH & Bal. & M & Libya & Mar- May & $\mathrm{RF}$ \\
\hline 4- Allium crameri Bornm. \& Gauba * & GH & Bal. & De, $S$ & Palestine & Mar- Apr & RF, SF \\
\hline $\begin{array}{l}\text { 5- Allium stamineum Boiss. subsp. decaisnei (C. } \\
\text { PresI) Kolllmann }\end{array}$ & GH & Bal. & $\mathrm{S}$ & Palestine & Feb- Mar & $\mathrm{RF}$ \\
\hline 6- Allium tel-avivense Eig & $\mathrm{Ge}$ & Bal. & M, De, S & Palestine & Feb.- Mar & CG, MH, RF \\
\hline \multicolumn{7}{|l|}{ Anacardiaceae } \\
\hline $\begin{array}{l}\text { 7- Pistacia khinjuk Stocks var. microphylla } \\
\text { Boiss. }\end{array}$ & $\mathrm{Ph}$ & Sar. & De & Saudi Arabia & Mar- Apr & MH \\
\hline \multicolumn{7}{|l|}{ Apiaceae (Umbelliferae) } \\
\hline 8- Bupleurum nanum Poir. & Th & Mic. & M & Libya & Feb- May & $\mathrm{RF}$ \\
\hline 9- Ducrosia ismaelis Asch. & $\mathrm{Hi}$ & Pog. & $\mathrm{O}$ & Saudi Arabia & - & $\mathrm{CF}$ \\
\hline 10- Ferula marmarica Asch. \& Taub. & $\mathrm{Ch}$ & Pte. & M, Dw & Libya & Feb- Apr & $\mathrm{RF}$ \\
\hline 11- Pimpinella etabica Schweinf. & Th & Pog. & GE & Sudan & Sep- Dec & $\mathrm{CF}$ \\
\hline 12- Pycnocycla tomentosa Decne. & $\mathrm{Hi}$ & Pog. & $\mathrm{S}$ & Saudi Arabia & Mar- June & $\mathrm{RF}$ \\
\hline \multicolumn{7}{|l|}{ Araceae } \\
\hline 13 -Biarum oliveri Blume & GH & - & M, S & Palestine & Nov- Dec & SF \\
\hline \multicolumn{7}{|l|}{ Arecaceae } \\
\hline $\begin{array}{l}\text { 14- Medemia argun (Mart.) Wuttemb. ex H. } \\
\text { WendI. }\end{array}$ & $\mathrm{Ph}$ & Bar. & $\mathrm{O}$ & Sudan & - & SF \\
\hline \multicolumn{7}{|l|}{ Asparagaceae } \\
\hline 15- Bellevalia desertorum Eig \& Feinbrun & $\mathrm{Ge}$ & Pte. & $\mathrm{S}$ & Palestine & March- Dec & SF \\
\hline 16- Bellevalia eigii Feinbrun & GH & Mic. & M, S & Palestine & Feb- Apr & CG \\
\hline 17- Bellevalia sessiliflora (Viv.) Kunth & GH & Bal. & $\mathrm{M}$ & Libya & Feb- Apr & SF, CF \\
\hline 18- Bellevalia zoharyi Feinbrun & GH & Bal. & $\mathrm{S}$ & Palestine & Mar- Apr & $\mathrm{RF}$ \\
\hline 19- Leopoldia eburnea Eig \& Feinbrun & Ge & Mic. & DW, S & Palestine & Feb- Mar & SF \\
\hline $\begin{array}{l}\text { 20- Leopoldia longipes (Boiss.) Losinsk. subsp. } \\
\text { negevensis Feinbrun \& } \text { Danin } \\
\end{array}$ & Ge & Mic. & $\mathrm{S}$ & Palestine & Mar- May & $\mathrm{RF}$ \\
\hline \multicolumn{7}{|l|}{ Asteraceae (Compositae) } \\
\hline 21- Atractylis boulosii Täckh. & Th & Des. & $\mathrm{S}$ & Palestine & Apr- Dec & SF \\
\hline
\end{tabular}




\section{Re-assessment of the near-endemic taxa in the Egyptian Flora}

Table 1. Cont. 1

\begin{tabular}{|c|c|c|c|c|c|c|}
\hline Taxa & $\begin{array}{c}\text { Life } \\
\text { form }\end{array}$ & $\begin{array}{c}\text { Dispersal } \\
\text { type }\end{array}$ & $\begin{array}{l}\text { Geographic } \\
\text { distribution }\end{array}$ & $\begin{array}{c}\text { Neighboring } \\
\text { country }\end{array}$ & $\begin{array}{c}\text { Flowering } \\
\text { time }\end{array}$ & Habitat \\
\hline 22- Carduncellus mareoticus (Delile) Hanelt & $\mathrm{Ch}$ & Des. & M, DW & Libya & Mar- Apr & Sf, CG, RS, FW \\
\hline $\begin{array}{l}\text { 23- Carthamus glaucuc M. Bieb. subsp. } \\
\text { alexandrinum (Boiss. \& Helder) Hanelt }\end{array}$ & Th & Pte. & $\mathrm{M}$ & Libya & May- Aug & RS, FW \\
\hline 24- Centaurea glomerata VahI & Th & Pog. & M & Libya & Mar- May & $\mathrm{CF}, \mathrm{RS}$ \\
\hline 25- Crepis libyca (Pamp.) Shab. & $\mathrm{Hi}$ & Pog. & $\mathrm{M}$ & Libya & Apr- May & CF \\
\hline 26- Phagnalon sinaicum Bornm. \& Kneuck. & Ch & Des. & $\mathrm{S}$ & Saudi Arabia & Mar- Apr & $\mathrm{RF}$ \\
\hline 27- Picris sulphurea Delile & Th & Des. & $\mathrm{N}, \mathrm{O}, \mathrm{D}, \mathrm{S}$ & Saudi Arabia & Mar- May & SF, PDW \\
\hline 28- Scorzonera drarii Täckh. * & $\mathrm{Hi}$ & Des. & $\mathrm{S}$ & Palestine & Mar- May & $\mathrm{CF}$ \\
\hline \multicolumn{7}{|l|}{ Boraginaceae } \\
\hline 29- Nonea vivianii A. DC. & Th & Pog. & $\mathrm{M}, \mathrm{S}$ & Libya & Mar- April & SF, CG, R \\
\hline 30- Podonosoma galalensis Schweinf. ex Boiss. & Th & Mic. & De & Palestine & Feb- June & $\mathrm{CG}, \mathrm{RF}$ \\
\hline \multicolumn{7}{|l|}{ Brassicaceae (Cruciferae) } \\
\hline 31- Enarthrocarpus pterocarpus (Pers.) DC. & Th & Pte. & $\mathrm{M}, \mathrm{S}$ & Libya & Feb- May & $\mathrm{CF}$ \\
\hline $\begin{array}{l}\text { 32- Isatis microcarpa Gay var. blephrocarpus } \\
\text { Asch. }\end{array}$ & Th & Pte. & $\mathrm{S}$ & Palestine & Mar-Apr & PDW, R \\
\hline \multicolumn{7}{|l|}{ Caprifoliaceae } \\
\hline 33- Pterocephalus arabicus Boiss. * & $\mathrm{Ch}$ & Pog. & $\mathrm{S}$ & Jordan & Apr- May & $\mathrm{RF}$ \\
\hline \multicolumn{7}{|l|}{ Caryophyllaceae } \\
\hline 34- Herinaria cyrenaica F. Herm. & $\mathrm{Hi}$ & Mic. & $\mathrm{M}$ & Libya & Mar- Dec & RF \\
\hline $\begin{array}{l}\text { 35- Minuartia picta (Sibth. \&Sm.) Bornm. var. } \\
\text { sinaica (Boiss.) Bornm. }\end{array}$ & Th & Bal. & $\mathrm{S}$ & Palestine & Feb- May & RF \\
\hline $\begin{array}{l}\text { 36- Pterohagia arabica (Boiss.) P.W. Ball \& } \\
\text { Heywood }\end{array}$ & Th & Bal. & $\mathrm{S}$ & Palestine & Apr- May & RF \\
\hline $\begin{array}{l}\text { 37- Silene biappendiculata Rohrb var. } \\
\text { biappendiculata }\end{array}$ & Th & Pog. & M, S & Libya & Feb- May & RF \\
\hline \multicolumn{7}{|l|}{ Cistaceae } \\
\hline $\begin{array}{l}\text { 38- Helianthemum sphaerocalyx Gauba \& } \\
\text { Janch. }\end{array}$ & Ch & Pog. & $\mathrm{M}$ & Libya & Feb- Apr & RF \\
\hline \multicolumn{7}{|l|}{ Colchicaceae } \\
\hline $\begin{array}{l}\text { 39- Colchicum cornigerum (Schweinf. ex } \\
\text { Sickneb.) Täckh. \& Drar * }\end{array}$ & $\mathrm{Ge}$ & Bal. & De, $S$ & Saudi Arabia & Nov- Dec & SF, RF \\
\hline \multicolumn{7}{|l|}{ Convolvulaceae } \\
\hline 40- Convolvulus schimperi Boiss. & $\mathrm{Hi}$ & Bal. & $\mathrm{S}$ & Saudi Arabia & Mar- June & SF, PDW \\
\hline 41- Convolvulus spicatus Haillier f. & $\mathrm{Hi}$ & Bal. & S & Palestine & Mar- June & SF, PDW \\
\hline \multicolumn{7}{|l|}{ Fabaceae (Leguminosae) } \\
\hline 42- Astragalus amalecitanus Boiss. & $\mathrm{Hi}$ & Pog. & $\mathrm{S}$ & Palestine & Mar- Apr & PDW \\
\hline 43- Astragalus camelroum Barbey* & $\mathrm{Hi}$ & Pog. & $\mathrm{S}$ & Palestine & Mar- June & $\mathrm{SF}, \mathrm{RF}$ \\
\hline 44- Ebenus armitagei Schweinf. \& Taub. & Ch & Pog. & $\mathrm{M}$ & Libya & Feb- May & $\mathrm{RF}$ \\
\hline 45- Lotus nubicus Baker & Th & Mic. & R, GE & Sudan & - & SF, PDW \\
\hline 46- Lupinus digitatus Forssk. * & Th & Pte. & $\mathrm{N}, \mathrm{D}$ & Lebanon & Feb- Apr & SF, FW \\
\hline 47- Lupinus palaestinus Boiss. & Th & Pte. & S & Palestine & Feb- Apr & $\mathrm{SF}, \mathrm{AL}$ \\
\hline $\begin{array}{l}\text { 48- Tephrosia purpurea (L.) Pers. subsp. } \\
\text { apollinea (Delile) Hosni \& El- Karemy }\end{array}$ & $\mathrm{Ch}$ & Pog. & N, De, R, GE & Sudan & Feb- Apr & BW, PDW \\
\hline 49- Trifolium philistaeum Zohary & Th & Mic. & $\mathrm{S}$ & Palestine & Mar- May & SF, PDW \\
\hline \multicolumn{7}{|l|}{ Fumariaceae } \\
\hline $\begin{array}{l}\text { 50- Hypecoum aegyptiacum (Forssk.) Asch. \& } \\
\text { Schweinf. }\end{array}$ & Th & Sar. & $\mathrm{N}, \mathrm{M}, \mathrm{S}$ & Palestine & Mar- Apr & SF \\
\hline 51- Hypecoum aequilobum Viv. & Th & Sar. & M, S & Libya & Mar- Apr & SF \\
\hline \multicolumn{7}{|l|}{ Gentianaceae } \\
\hline 52- Centaurium malzacianum Maire & Th & Bal. & $\mathrm{S}$ & Saudi Arabia & Apr- May & RF \\
\hline \multicolumn{7}{|l|}{ Hydrocharitaceae (Valerianaceae) } \\
\hline 53- Valerianella pterovitchii Asch. & Th & Des. & M & Libya & Mar- Apr & SF \\
\hline
\end{tabular}




\section{Shaltout et al.}

Table 1. Cont. 2

\begin{tabular}{|c|c|c|c|c|c|c|}
\hline Taxa & $\begin{array}{l}\text { Life } \\
\text { form }\end{array}$ & $\begin{array}{l}\text { Dispersal } \\
\text { type }\end{array}$ & $\begin{array}{l}\text { Geographic } \\
\text { distribution }\end{array}$ & $\begin{array}{l}\text { Neighboring } \\
\text { country }\end{array}$ & $\begin{array}{l}\text { Flowering } \\
\text { time }\end{array}$ & Habitat \\
\hline \multicolumn{7}{|l|}{ Iridaceae } \\
\hline 54- Iris mariae Barbey & $\mathrm{Ge}$ & Bal. & $\mathrm{S}$ & Palestine & Feb- Mar & SF \\
\hline \multicolumn{7}{|l|}{ Lamiaceae (Labiatae) } \\
\hline 55- Micromeria sinaica Benth. & $\mathrm{Ch}$ & Mic. & $\mathrm{S}$ & Palestine & Mar- May & RF \\
\hline 56- Origanum isthmicum Danin & $\mathrm{Ch}$ & Mic. & $\mathrm{S}$ & Palestine & Mar- June & RF \\
\hline 57- Thymus bovei Benth. & $\mathrm{Ch}$ & - & De, S & Palestine & June- July & RF \\
\hline \multicolumn{7}{|l|}{ Plantaginaceae } \\
\hline 58-Plantago sinaica (Barn.) Decne. * & $\mathrm{Ch}$ & Bal. & $\mathrm{S}$ & Jordan & Mar- Apr & MH, RF, PDW \\
\hline \multicolumn{7}{|l|}{ Ranunculaceae } \\
\hline 59- Delphinium bovei Decne. & Th & - & $\mathrm{S}$ & Palestine & Mar- May & SF,PDW \\
\hline 60- Nigella deserti Boiss. & Th & Bal. & $\mathrm{S}$ & Palestine & Apr- July & SF \\
\hline $\begin{array}{l}\text { 61- Nigella arvensis L. var. beersherensis } \\
\text { Zohary }\end{array}$ & Th & Bal. & $\mathrm{S}$ & Palestine & Apr- July & SF \\
\hline \multicolumn{7}{|l|}{ Rutaceae } \\
\hline $\begin{array}{l}\text { 62- Haplophyllum poorei C. C. Towns. subsp. } \\
\text { negevensis Zohary \& Danin }\end{array}$ & Ch & Des. & $\mathrm{S}$ & Palestine & Mar- May & RF \\
\hline \multicolumn{7}{|l|}{ Scrophulariaceae } \\
\hline $\begin{array}{l}\text { 63- Kickxia floribunda (Boiss.) Täckh. \& } \\
\text { Boulos }\end{array}$ & $\mathrm{Ch}$ & Bal. & De, $\mathrm{S}$ & Palestine & Mar- Aug & $\begin{array}{l}\text { SF, RF, } \\
\text { DPW }\end{array}$ \\
\hline 64- Kickxia macilenta (Decne.) Danin & $\mathrm{Ch}$ & Bal. & $\mathrm{S}$ & Palestine & Mar- May & $\mathrm{MH}, \mathrm{RF}$ \\
\hline 65- Linaria joppensis Bornm. & Th & Bal. & $\mathrm{S}$ & Palestine & Mar- April & SF \\
\hline 66- Verbascum fruticulosum Post & Ch & Bal. & $\mathrm{S}$ & Palestine & Apr- Aug & RF, PDW \\
\hline 67- Verbascum letourneuxii Asch. \& Schweinf. & $\mathrm{Hi}$ & Bal. & $\mathrm{M}$ & Libya & Apr- May & RF, RS \\
\hline \multicolumn{7}{|l|}{ Solanaceae } \\
\hline $\begin{array}{l}\text { 68- Lycium schweinfurthii Dammer var. } \\
\text { aschersohnii (Dammer) Feinbrun }\end{array}$ & $\mathrm{Ph}$ & Sar. & $\mathrm{M}$ & Palestine & All the year & CF \\
\hline 69- Withania obtusifolia Täckh. & $\mathrm{Ph}$ & Sar. & S, GE & Palestine & - & $\mathrm{MH}, \mathrm{RF}$ \\
\hline \multicolumn{7}{|l|}{ Tamariaceae } \\
\hline 70- Reaumuria negevensis Zohary \& Danin & $\mathrm{Ch}$ & Pte. & $\mathrm{S}$ & Palestine & May- June & RF \\
\hline \multicolumn{7}{|l|}{ Zygophyllaceae } \\
\hline 71- Fagonia mollis Delile var. hispida Zohary & $\mathrm{Ch}$ & Des. & De, $S$ & Palestine & Mar- Apr & SF, RF, PDW \\
\hline 72- Fagonia taeckholmiana Hadidi & Ch & Bal. & De & Libya & Apr- May & SF \\
\hline 73- Zygophyllum dumosum Boiss. & Ch & Pte. & De, $S$ & Palestine & Mar- Apr & MH, RF, PDW \\
\hline
\end{tabular}

Table 2. Habitats of the near-endemic taxa in Egypt in relation to their taxonomic diversity.

\begin{tabular}{|c|c|c|c|c|c|}
\hline \multirow{2}{*}{ Habitat } & \multicolumn{5}{|c|}{ Taxon } \\
\hline & Family & Genus & Species & Subspecies & Variety \\
\hline Banks of water bodies (BW) & 1 & 1 & - & 1 & - \\
\hline $\begin{array}{l}\text { Desert plains, depressions and wadis } \\
\text { (PDW) }\end{array}$ & 11 & 15 & 12 & 1 & 3 \\
\hline Sandy formations (SF) & 16 & 24 & 28 & - & 2 \\
\hline Alluvial soil (AL) & 1 & 1 & 1 & - & - \\
\hline Cultivated fields (CF) & 5 & 7 & 6 & - & 1 \\
\hline Mountains and hills (MH) & 6 & 6 & 5 & - & 1 \\
\hline Rocky surfaces (RF) & 19 & 31 & 31 & 2 & 3 \\
\hline Road sides (RS) & 2 & 4 & 3 & 1 & - \\
\hline Calcareous ground (CG) & 4 & 5 & 5 & - & - \\
\hline Ridges (R) & 2 & 2 & 1 & - & - \\
\hline Fallow fields and waste ground (FW) & 2 & 3 & 2 & 1 & - \\
\hline
\end{tabular}




\section{Re-assessment of the near-endemic taxa in the Egyptian Flora}

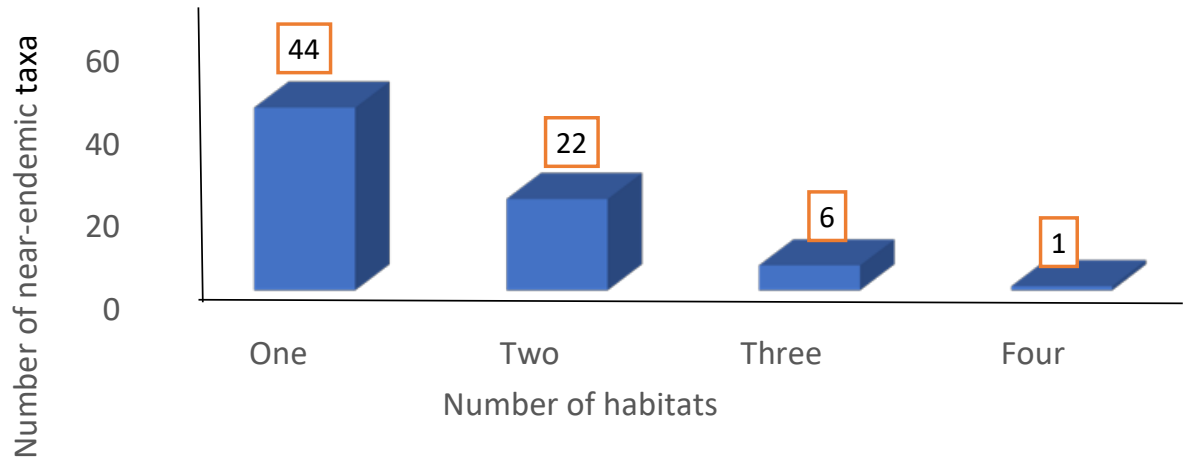

Fig. 1. Number of near-endemic taxa in the Egyptian flora in relation to the number of habitats in which they occur

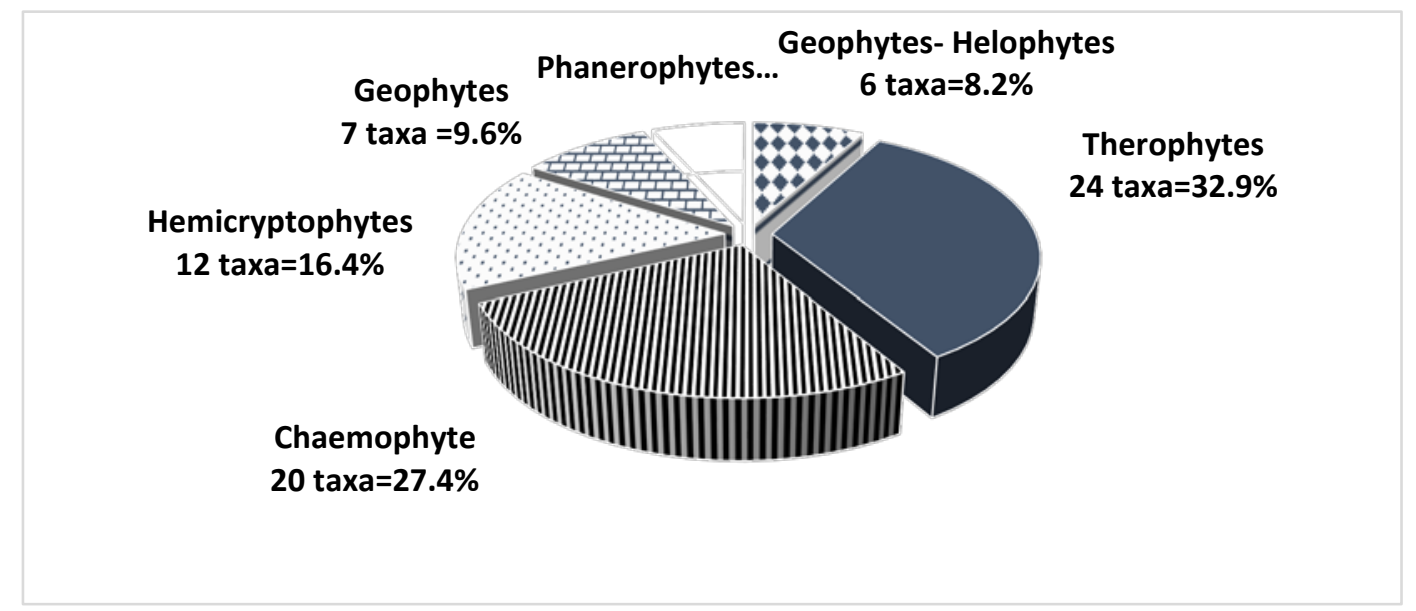

Fig. 2. Life form spectrum of the 73 near-endemic taxa in the Egyptian flora.

All the near-endemic taxa are bisexual, except two taxa that are unisexual dioecious plants (Pistacia khinjuk var. microphylla and Medemia argun). Determination of dispersal type indicated that the ballochores $(22$ taxa $=$ $31.4 \%$ of the total species) are the most represented dispersal type, followed by pogonochore $(15$ taxa $=21.4 \%)$ and microsclerochores $(10$ species $=14.3)$ (Fig. 3$)$. Sixty-nine taxa $(94.5 \%)$ had available data about their flowering time. There is a gradual increase in the frequency of the flowered taxa from December till reaching a maximum in March (51 taxa), followed by April (45 taxa) and May (34 taxa). In general, the period from March to May was characterized by the highest flowering activity, while the period from August to January was the lowest (Fig. 4).

Fifty one near-endemic taxa are stenonear-endemics (69.9 \% of the total taxa) which occur in only one national phyto-geographical region: 33 taxa in Sinai, 12 in Mediterranean, 2 in Oases, 3 in Eastern desert, 1 in Gebel Elba (Pimpinella etabica). In addition, 18 taxa occur in 2 regions (24.3\%), 2 in 3 regions (Allium tel-avivense and Hypecoum aegyptiacum) (2.7\%) and 2 in 4 regions (2.7 \%) (Fig. 5). Sinai region is the most rich in near-endemic species as it includes 24 families and 50 taxa, followed by the Mediterranean region (13 families \& 22 taxa) and Eastern Desert (8 families \& 11 taxa) (Fig. 6). 


\section{Re-assessment of the near-endemic taxa in the Egyptian Flora}

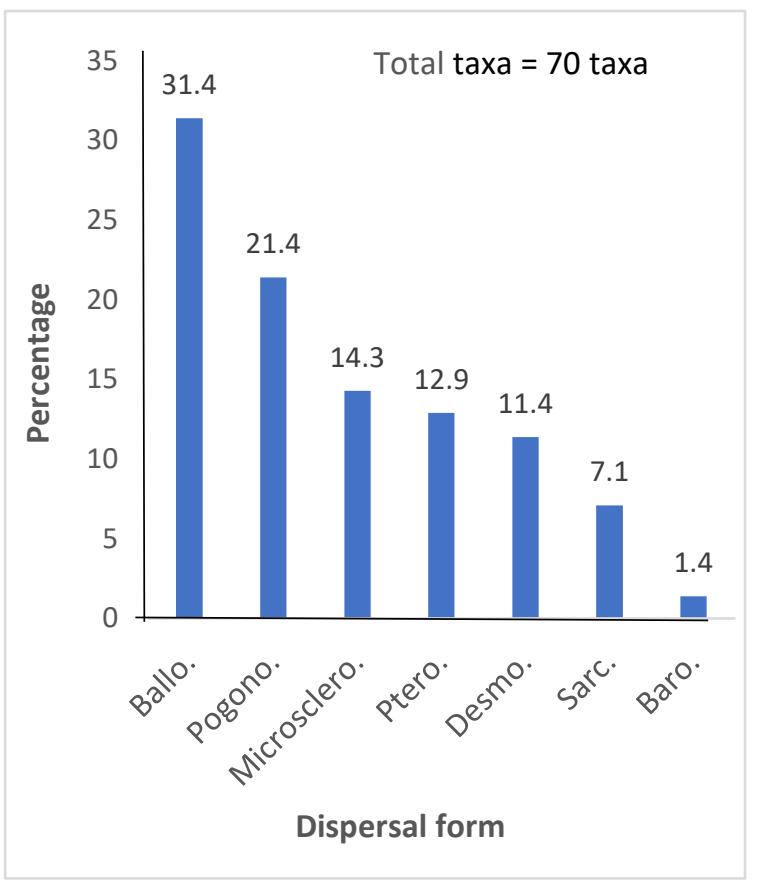

Fig. 3. Dispersal type spectrum of the near-endemic taxa in the Egyptian flora.

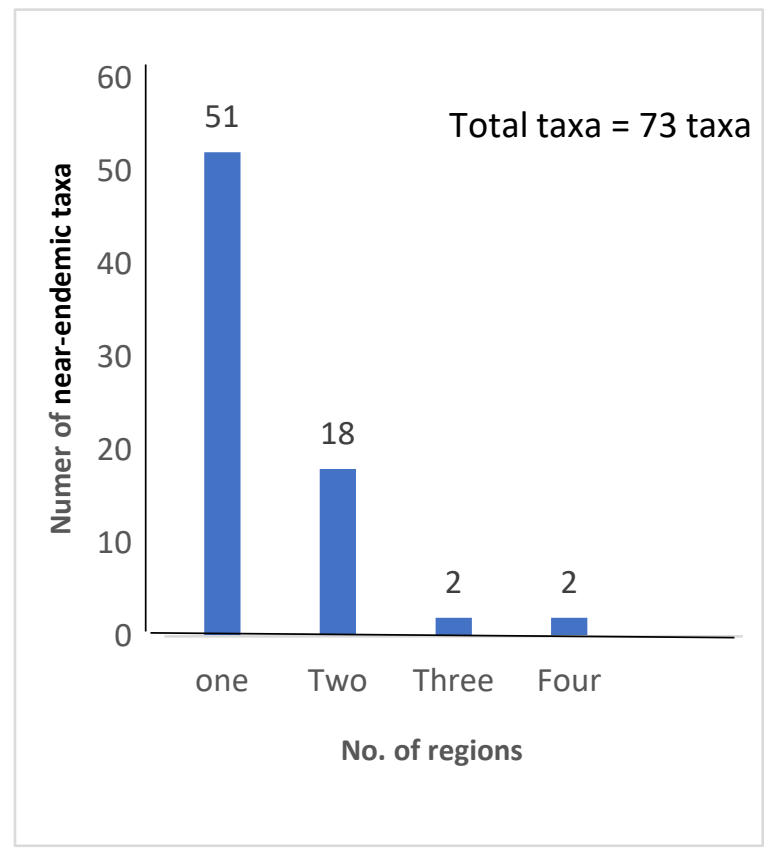

Fig. 5. Number of near-endemics in Egyptian flora in relation to the number of phyto-geographical regions.

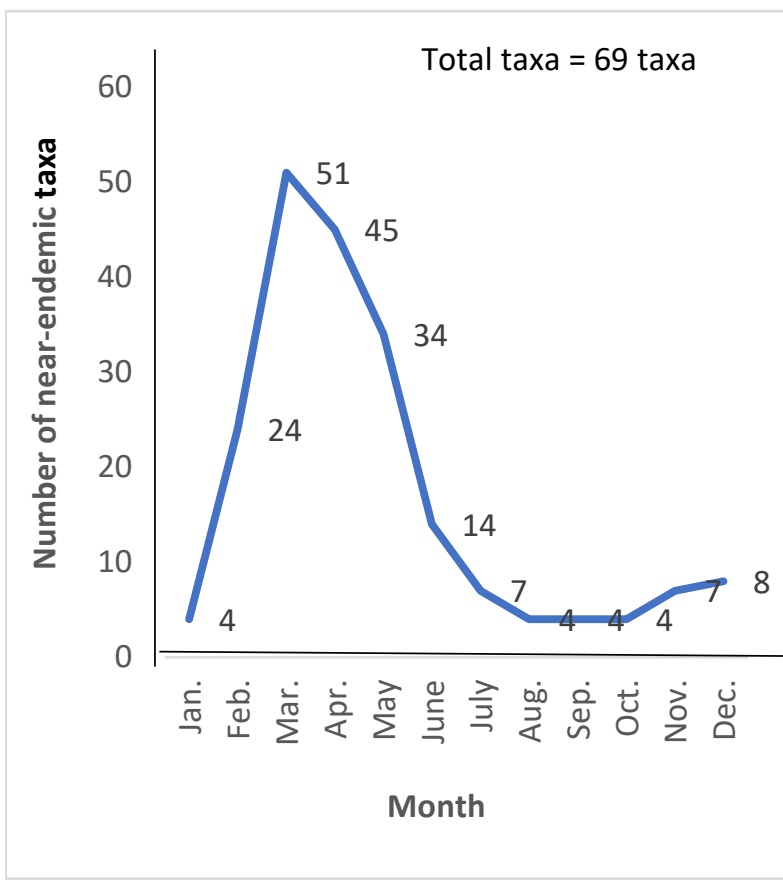

Fig. 4. Number of the near-endemic taxa in the Egyptian flora in relation to their flowering time.

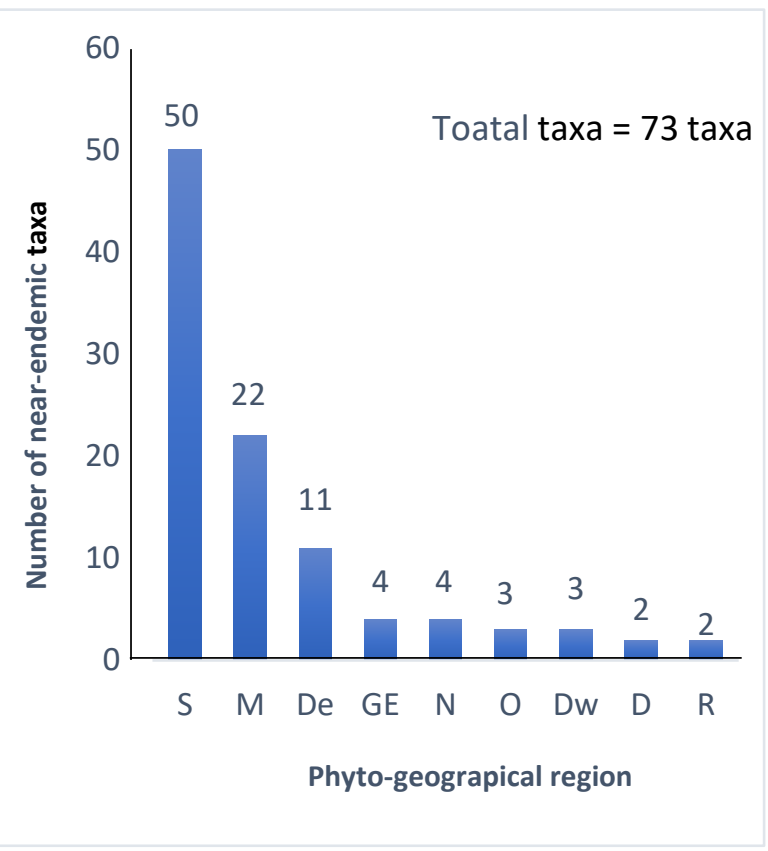

Fig. 6. Number of near-endemic taxa in the Egyptian flora in relation to the national phyto-geographical regions. S: Sinai Peninsula, M: Mediterranean coastal region, De: Desert east of the Nile, GE: Gebel Elba region, $\mathrm{N}$ : Nile region including delta, Valley and Faiyum, O: Oases of the western desert, Dw: Desert west of the Nile, D: All deserts of Egypt except that of Sinai and R: Red Sea region. 


\section{Shaltout et al.}

The relation between the number of nearendemic taxa and the rarity forms indicated that most of them (69 taxa $=94.5 \%$ ) belong to the cell of small geographic range- small habitat- non abundant plants (SNN); while the rest 4 taxa (5.5\%) belong to the cell of small geographic range- small habitat- abundant plants (SNA). All of the near-endemic taxa have at least one aspect of the potential or actual economic goods. The goods are classified into 5 major groups: medicinal, grazing, human food, fuel and other uses (e.g. esthetic concerns, oil, industry, fodder, weaving). The offered goods could be arranged descendingly as follows: medicinal $(51$ taxa $=69.9 \%)$, other uses (20 taxa $=27.4$ $\%)$, grazing (16 taxa $=21.9 \%)$, human food (11 taxa $=15.1 \%)$, and fuel ( 1 taxon $=1.4 \%$ ) (Fig. 7). Forty- seven taxa have only one good (64.4 $\%), 24$ taxa have two goods (32.9\%), while 2 taxa have three goods $(2.7 \%)$. The available information about the services of the nearendemic taxa in the Egyptian flora is very scarce due to the rarity of most of these taxa and extinction of others. According to the available data in the present study, most services offered by the near-endemics are sand accumulation (3 taxa), soil fertility and nitrogen fixation (8 taxa), wind breaking (5 taxa) and shading (2 taxa). All the nearendemic taxa were exposed to at least one aspect of threats, which are classified into 8 major groups: over- collecting and overcutting, habitat loss, browsing and over grazing, clearance for agriculture, mining and quarrying, disturbance by cars or trampling, urbanization and tourism and climatic changes and environmental conditions. The threats upon the near-endemic species could be arranged descendingly as follows: overcollecting and over-cutting (73 taxa $=100 \%$ ), urbanization and tourism, browsing and overgrazing (each of 25 taxa $=34.2 \%$ ), habitat loss (24 taxa $=32.9 \%)$, clearance for agriculture (20 taxa $=27.4 \%$ ), mining and quarrying, climatic changes and environmental conditions $(14$ taxa $=19.2 \%)$ (Fig. 8).

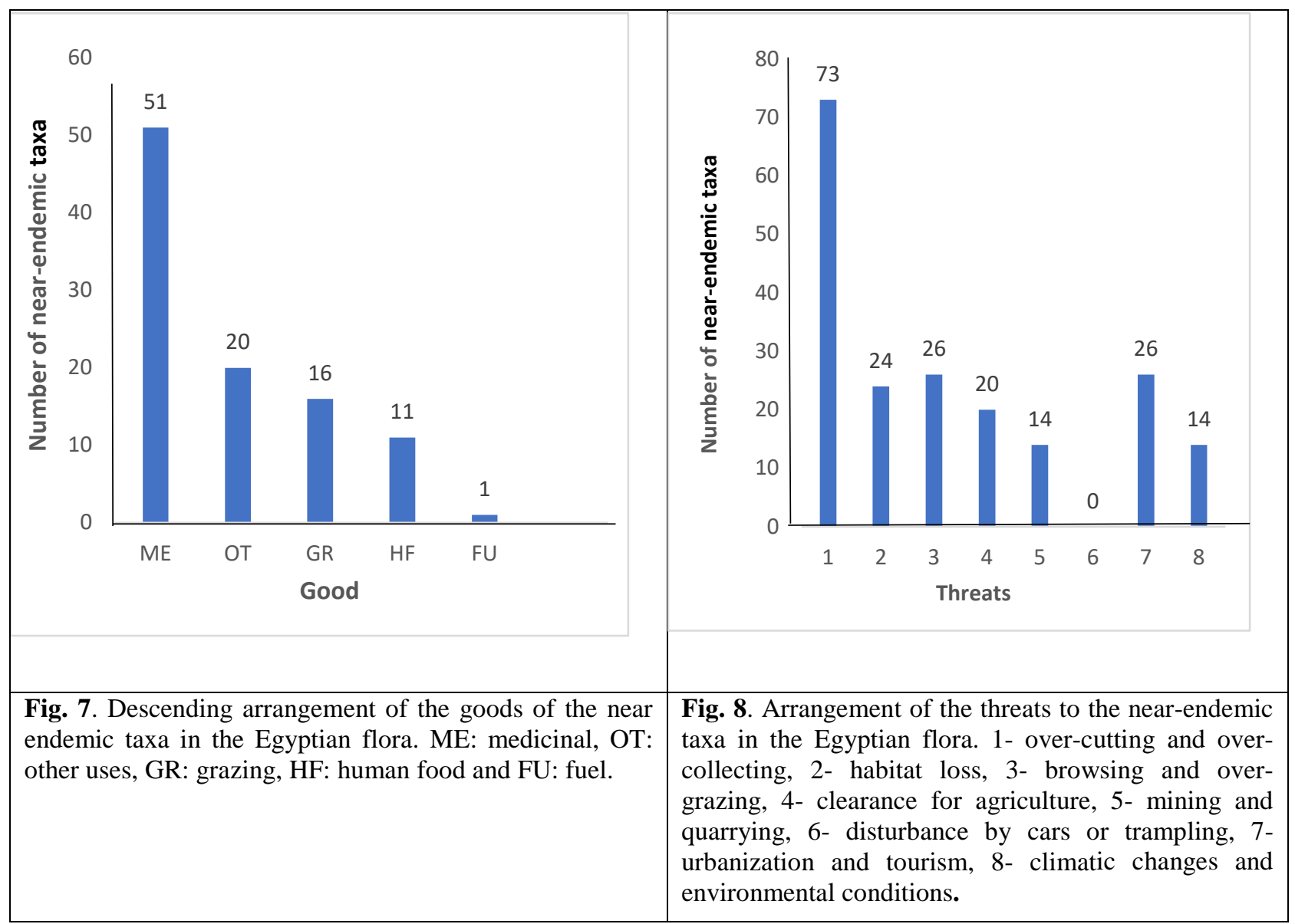




\section{Shaltout et al.}

The evaluation process was carried out depending on IUCN categories (2003- 2010). The present study depended on the criteria of geographical range of plants (extent of occurrence EOO and Area of occupancy AOO). Among the 30 near-endemic taxa which were evaluated in the present study, $\mathbf{5}$ taxa were assessed as critically endangered
(16.7\% of the total assessed near-endemics), 12 taxa endangered (40 \%), while 4 taxa (13.3 $\%)$ are believed to be extinct and $\mathbf{1}$ vulnerable (3.3\%). On the other hand, 8 taxa have no adequate information about their occurrence (26.7 \%) (even as herbarium specimens), so they were evaluated under category of data deficient (Fig. 9 and Table 3).

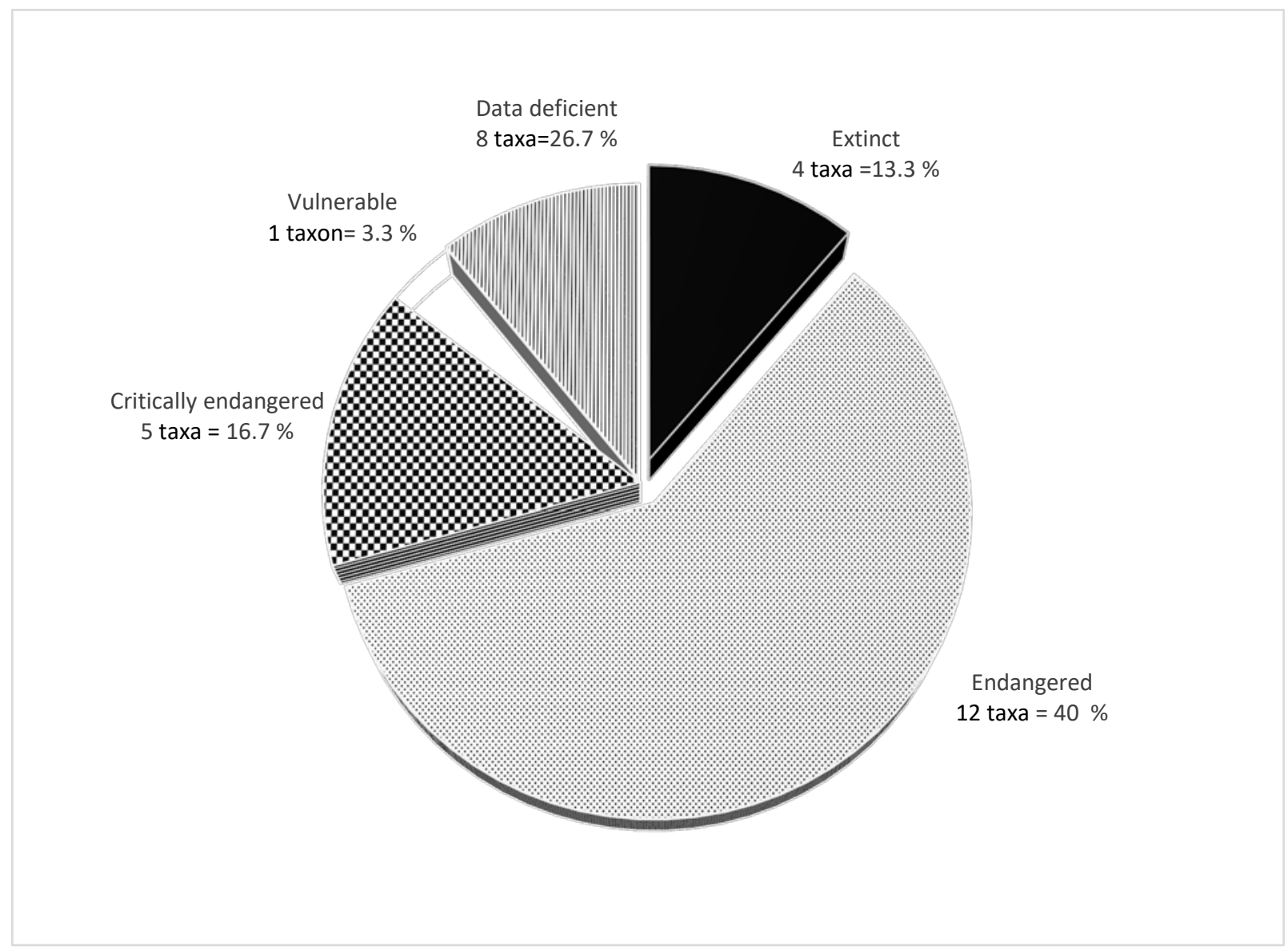

Fig. 9. IUCN categories of 30 of the near-endemic taxa in the Egyptian flora.

Based on the present as well as the previous studies (IUCN 1998, EL-Hadidi and Hosni 2000 and Hosni et al. 2013), 66 out of 73 near-endemics are evaluated, of these: 27 endangered (40.9\%), 16 critically endangered (24.2 \%), 8 vulnerable (12.1 \%), 8 data deficient (12.1\%), 2 rare (3.0\%), 4 extinct (6.1
$\%)$ and 1 least concern (1.5). On the other hand, 7 taxa were not evaluated in the present study as well as the previous studies, thus they should take priority in any forthcoming evaluation, in addition to 8 data deficient taxa (Table 3). 


\section{Re-assessment of the near-endemic taxa in the Egyptian Flora}

Table 3. Comparison of the red list evaluation of the near-endemic taxa of the present study with three previous studies according to IUCN categories. These studies are abbreviated as follows: I: Hosni et al. (2013), II: ELHadidi and Hosni 2000 and III: IUCN 1998. The conservation categories are abbreviated as follow: EN: endangered, VU: vulnerable, LC: least concern, RA: rare, IN: indeterminate, CR: critically endangered, EX: extinct, RE: regionally extinct and DD: data deficient. EOO: extent of occurrence, AOO: area of occupancy.

\begin{tabular}{|c|c|c|c|c|c|c|}
\hline \multirow[t]{2}{*}{ Latin name } & \multicolumn{2}{|c|}{ Present study } & \multicolumn{3}{|c|}{ Previous studies } & \multirow[t]{2}{*}{ Final } \\
\hline & EOO & AOO & $\mathbf{I}$ & II & III & \\
\hline \multicolumn{7}{|c|}{ Near-endemic taxa } \\
\hline Allium crameri & - & - & EN & RA & - & EN \\
\hline Allium tel-avivens & - & - & - & - & - & - \\
\hline Bellevalia eigii & - & & - & EN & - & EN \\
\hline Biarum olliveri & - & - & - & EN & - & EN \\
\hline Carduncellus mareoticus & CR & CR & NT & - & - & CR \\
\hline Colchicum cornigerum & - & - & VU & EN & - & EN \\
\hline Enarthrocarpus pterocarpus & - & - & CR & - & - & CR \\
\hline Fagonia mollis var.hispida & EN & EN & LC & - & - & EN \\
\hline Ferula marmarica & CR & CR & NT & - & - & CR \\
\hline Hypecoum aegyptiacum. & - & - & LC & - & - & LC \\
\hline Hypecoum aequilobum & DD & $\mathrm{DD}$ & VU & IN & - & DD \\
\hline Kickxia floribunda & - & - & VU & - & - & VU \\
\hline Leopoldia eburnea & - & - & EN & - & - & EN \\
\hline Lotus nubicus & EN & EN & - & - & - & EN \\
\hline Lupinus digitatus & - & - & EN & EN & - & EN \\
\hline Nonea vivianii . & - & - & VU & - & RA & VU \\
\hline Picris sulphureae & - & - & - & - & - & - \\
\hline Silene biappendiculata var. biappendiculata & DD & DD & NT & - & - & DD \\
\hline Tephrosia purpureae subsp. apollinea & - & - & - & - & - & - \\
\hline Thymus bovei & DD & DD & NT & VU & - & DD \\
\hline Withania obtusifolia . & EN & EN & - & VU & - & EN \\
\hline Zygophyllum dumosum. & EN & EN & - & VU & - & EN \\
\hline \multicolumn{7}{|c|}{ Steno-near-endemic taxa } \\
\hline Allium barthianum & EN & VU & $\mathrm{RE}$ & RA & - & VU \\
\hline Allium stamineum subsp. decaisnei & CR & EN & - & - & - & EN \\
\hline Anabsis syriaca var. syriaca & - & - & VU & VU & - & VU \\
\hline Astragalus amalcitanus & - & - & VU & - & - & VU \\
\hline Astragalus camelroum & - & - & EN & EN & RA & EN \\
\hline Atractylis boulosii & - & - & - & - & RA & RA \\
\hline Bellevalia desertorum & - & - & - & - & - & - \\
\hline Bellevalia sessiliflora & - & - & - & - & - & - \\
\hline Bellevalia zoharyi & - & - & - & - & - & - \\
\hline Bupleurum nanum & - & - & CR & - & - & CR \\
\hline Carthamus glaucuc subsp. alexandrinum & EN & EN & VU & - & - & EN \\
\hline Centaureae glomerata & EN & EN & EN & - & - & EN \\
\hline Centaurium malzacianum & DD & $\mathrm{DD}$ & NT & IN & - & DD \\
\hline Convolvulus schimperi. & - & - & EN & RA & - & EN \\
\hline Convolvulus spicatus. & - & - & $\mathrm{CR}$ & - & - & CR \\
\hline Crepis libyca & EX & EX & $\mathrm{RE}$ & - & IN & EX \\
\hline Delphinium bovei & - & - & - & EN & - & EN \\
\hline Ducrosia ismaelis & - & - & CR & EN & - & CR \\
\hline Ebenus armitagei & - & - & CR & EN & - & CR \\
\hline Fagonia taeckholmiana & EX & EX & - & EX & - & EX \\
\hline Haloxylon negevensis & DD & DD & VU & IN & - & DD \\
\hline Haplophyllum poorei & - & - & EN & - & - & EN \\
\hline Helianthemum sphaerocalyx & - & - & - & EN & - & EN \\
\hline Herniaria cyrenaica & DD & DD & DD & - & - & DD \\
\hline Iris mariae & EX & EX & $\mathrm{RE}$ & RA & - & EX \\
\hline Isatis microcarpa var. blepharocarpus & CR & EN & VU & RA & - & EN \\
\hline Kickxia macilenta & - & - & - & RA & - & RA \\
\hline
\end{tabular}


Shaltout et al.

Table 3. Cont. 1

\begin{tabular}{|l|c|c|c|c|c|c|}
\hline \multirow{2}{*}{ Latin name } & \multicolumn{2}{|c|}{ Present study } & \multicolumn{3}{c|}{ Previous studies } & Final \\
\cline { 2 - 6 } & EOO & AOO & I & II & III & \\
\hline Leopoldia longipes subsp. negevensi. & - & - & EN & - & - & EN \\
Linaria joppensis & - & - & VU & - & - & VU \\
Lupinus palaestinus & - & - & CR & EN & - & CR \\
Lycium schweinfurthii var. aschersohnii & - & - & VU & - & - & VU \\
Medemia argun & - & - & - & EN & EN & EN \\
Micromeria sinaica & CR & CR & VU & RA & RA & CR \\
Minuartia picta var.sinaica. & CR & CR & VU & - & - & CR \\
Nigella arvensis var. beersherensis & DD & DD & NT & - & - & DD \\
Nigella deserti & - & - & CR & - & - & CR \\
Origanum isthmicum & - & - & - & EN & RA & EN \\
Phagnalon sinaicum. & CR & EN & EN & RA & - & EN \\
Pimpinella etabica & - & - & CR & RA & - & CR \\
Pistacia khinjuk var. microphylla & - & - & - & - & - & - \\
Plantago Sinaica & EN & EN & CR & - & - & EN \\
Podonosoma galalensis. & CR & CR & CR & IN & - & CR \\
Pterocephalus arabicus & - & - & CR & EN & RA & CR \\
Pterohagia arabica & - & - & VU & - & - & VU \\
Pycnocycla tomentosa. & EN & EN & VU & - & - & EN \\
Reaumuria negevensis & DD & DD & NT & RA & - & DD \\
Scorzonera drarii & EX & EX & EX & EN & EN & EX \\
Trifolium philistaeum & - & - & CR & - & - & CR \\
Valerianell petrovitchii & - & - & - & EN & - & EN \\
Verbascum fruticulosum & - & - & CR & RA & - & CR \\
Verbascum letourneuxii & EN & EN & VU & EN & - & EN \\
\hline Total & 30 & $\mathbf{3 0}$ & $\mathbf{5 3}$ & $\mathbf{3 6}$ & $\mathbf{9}$ & $\mathbf{6 6}$ \\
\hline
\end{tabular}

\section{Discussion}

Near-endemics in the present study are the plants restricted to only two adjacent countries (Boulos 2009). According to this study, the near-endemics are 73 taxa of vascular plants belonged to 58 genera and 28 families. Comparing with the previous studies, Boulos (2009) reported that the near-endemic taxa in Egypt are 93, while Hosni et al. (2013) reduced the number to 61 . Recent records were collected from the literature, scientific websites and global databases with specific locality, coordinates, and photos or herbarium specimens, to assess the recent distribution of the near-endemics, while taxa mentioned in a single report or research without their documentation with photos or herbarium specimens were not excluded from the nearendemics in the present work.

Twenty-two taxa in the present study were recorded also in Boulos (2009) and Hosni et al. (2013) as near-endemics. In addition, 6 near-endemics in the present study were recorded only in Hosni et al. (2013) (Anabsis syriaca var. syriaca, Astragalus camelroum, Isatis microcarpa var. blephrocarpus, Nigella arvensis var. beersherensis, Plantago Sinaica and Thymus bovei), while 38 were recorded only in Boulos (2009). Morever, 7 taxa in the present study were moved from endemics to near-endemics (Allium crameri, Colchicum cornigerum, Lupinus digitatus, Plantago sinaica, Pterocephalus arabicus, Origanum isthmicum and Scorzonera drarii).

In contrast with the two previous studies (Boulos 2009 and Hosni et al. 2013), 13 species were excluded from the nearendemics: 9 of them were reported in Egypt and Palestine (Atractylis serratuloides, Onopordum alexandrinum, Campanula dulcis, Astragalus caprinus, Astragalus trimestris, Galium sinaicum, Solanum sinaicum, Aegilops longissima and Verbascum shimperianum), two in Egypt and Saudi Arabia (Hypericum sinaicum and Thymus decussatus) and two in Egypt and Libya (Valantia lanata and Centaurea alexandrina), as they were also recorded in other countries. Atractylis serratuloides was recorded in Libya (Jafri and El- Gadi 1983) and Algeria (website 8 and website 16); Onopordum alexandrinum in Palestine, Jordan, Lebanon and Syria (http://ww2.bgbm.org); Campanula dulcis in Saudi Arabia and Yemen (Collenette 1999, website 15, website 17 and website 6); Astragalus caprinus in Libya (Jafri and ElGadi 1980), Morocoo, Tunisia, Turkey, Iran 


\section{Re-assessment of the near-endemic taxa in the Egyptian Flora}

and Saudi Arabia (website 6); and Astragalus trimestris in Libya (website 15), Spain and United States (website 6). Galium sinaicum, Verbascum shimperianum and Solanum sinaicum were recorded also in Saudi Arabia (Migahid 1989 and website 6); Aegilops longissima in Turkey, Afghanistan, USA, Uzbekistan, Australia, Iran, Spain and Lebanon (website 6); Hypericum sinaicum in Ethiopia (website 8); Thymus decussatus in Palestine (website 15); Valantia lanata in Tunisia (website 6); and Centaurea alexandrina in Mali (website 8), Niger, Sudan, France and Spain (website 6).

In the present study, 19 species were excluded from the near-endemics, while they were reported as near-endemics in Boulos (2009): 11 in Egypt and Palestine (Blepharis attenuata, Alliun desertorum, Ornithogallum trichophyllum, Anthemis indurata, Lobularia arabica, Nasturtiopsis coronopifolia, Astragalus fruticosus, Nepeta septemcrenata, Plantago cryopsides, Reseda stenostachya and Veronica scardica); 5 in Egypt and Libya (Salsola longifolia, Echinops galaensis, Isatis microcarpa, Euphorbia parvula and Euphorbia punctata); 2 in Egypt and Saudi Arabia (Colchicum guessfeldtianum and Tavernieria aegyptiaca), and one in Egypt and Sudan (Lotus herbanicus). The exclusion is due to the following justifications: Blepharis attenuata was recorded also in Jordan (Taifour and El-Qolah 2014), Syria and Saudi Arabia (websites 6 and 16); Alliun desertorum in Saudi Arabia and Kuwait (Migahid 1989 and website 6); Ornithogallum trichophyllym in Libya (Jafri and El-Gadi 1978), Turkey (website 8) and Iraq (website 6); Anthemis indurata in Libya (Jafri and El-Gadi 1983) and Saudi Arabia (Migahid 1989); Lobularia arabica in Libya (website 14), Lebanon (website 18) and Greece (website 6). Nasturtiopsis coronopifolia was recorded also in Libya ( Jafri and El-Gadi 1977) Algeria, Tunisia and Saudi Arabia (websites 6 and 8); Astragalus fruticosus in Libya (Jafri and ElGadi 1980), Saudi Arabia (Migahid 1989) Russia and Mangolia (website 6); Nepeta septemcrenata in Saudi Arabia (Migahid 1989) and Iran (websites 6 and 8); Plantago cryopsides in Malta (website 14), Kuwait, Bahrain, Jordan, Saudi Arabia and Iran (website 6); Reseda stenostachya in Turkey (Davis et al. 1978; websites 6, 8 and 16) and Saudi Arabia (website 5); Veronica scardica in Albania, Hungary, Slovakia, Australia, Turkey, Germany, Syria and Georgia with specific locations and coordinates (websites 6 and 8).

In addition, Euphorbia parvula was recorded also in France (website 8); Euphorbia punctata in Turkey, Azerbaijan and Ecuador (websites 6 and 8); Salsola longifolia in Saudi Arabia (Migahid 1988), Mouritania, Algeria, Morocco, Tunisia and Spain (websites 6 and 8); Echinops galaensis in Saudi Arabia (Migahid 1989, Al-Yayha et al. 1990 and ElShabasy 2016), Kuwait, Yemen and Emirates (website 6); Isatis microcarpa in Saudi Arabia, Palestine, Jordan, Morocco, and Afghanistan with specific locations and coordinates (websites 6 and 8); Colchicum guessfeldtianum was reported as synonym to Colchicum shimperi (website 2) and recorded also in Yemen, Iran, Bulgharia (website 8), Saudi Arabia, Iraq, Lebanon, Syria, Palestine and Yemen (websites 19 and 6); Tavernieria aegyptiaca was recorded also in Sudan, Djibouti, Ethiopia (websites 4 and 20) and Qatar (Botanouny 1981 and website 6), and Lotus herbanicus in Saudi Arabia (websites 6, 8 and 21).

In the present study, 20 taxa were excluded from the near- endemics, while reported as near-endemics in Hosni et al. (2013): 8 of them occur in Egypt and more than one adjacent country (Allium sinaiticum, Centaurea scoparia, Dianthus sinaicus, Iphiona mucronata, Pterocephalus sanctus, Polygala negevensis, Rhus flexicaulis, and Rhamnus dispermus). Also, 4 taxa in Egypt and Palestine (Allium roseum var. tourneauxii, Phagnalon nitidum, Salvia deserti and Stachys aegyptiaca), 2 in Egypt and Jordan (Anthemis melampodina subsp. deserti and Anthemis scrobicularis), 2 in Egypt and Arabia (Asclepias sinaica and Commiphora quadricincta), 2 in Egypt and Libya (Indigofera lotononoides and Stipagrostis shawii), while Euporbia bivonae var. sinaica and Teuricum leucocladum subsp. leucocladum var leucocldum recorded in Hosni et al. (2013), were excluded as they were not reported in the books dealing with the 


\section{Shaltout et al.}

Egyptian flora (e.g. Täckholm et al. 1941, Täckholm and Drar 1950- 1969, Täckholm 1974 and Boulos 1999-2009).

The exclusion was due to the following justifications: Centauraea scoparia, and Iphiona mucronata were recorded also in Palestine, Jordan and Saudi Arabia (Boulos 2002, websites 6 and 8); Allium sinaiticum in Palestine, Jordan and Saudi Arabia (Boulos 2005 and website 6); Dianthus sinaicus in Palestine and Saudi Arabia (Boulos 1999 and website 6); Rhus flexicaulis in Sudan and Arabia (Boulos 2000), Yemen and Oman (websites 6 and 8); Pterocephalus sanctus in Palestine and Saudi Arabia (Boulos 2002); Polygala negevensis in Saudi Arabia (Boulos 2000, websites 6 and 8); and Rhamnus dispermus in Lebanon (Boulos 2000), Banama and Saudi Arabia (website 8). In addition, Allium roseum var. tourneauxii was recorded also in Libya (Boulos 2005); Phagnalon nitidum in Iran (website 8), Ethiopia, Pakistan and Eiteria (website 6); Salvia deserti in Palestine, Arabia (Boulos 2002 and website 6) Jordan and Saudi Arabia (website 6); Stachys aegyptiaca in Saudi Arabia and Spain (Boulos 2002 and website 6); Anthemis melampodina subsp. deserti in Libya ( Jafri and El- Gadi 1983), Kuwait and Saudi Arabia (Al-Rawi 1987 and website 6), Anthemis scrobicularis in Palestine, Arabia (Boulos 2002) and Saudi Arabia (websites 6 and 8); Asclepias sinaica in Syria and Jordan (websites 6 and 8); Commiphora quadricincta in Sudan and Arabia (Boulos 2000) Eritrea, Saudi Arabia, Nigeria and Yemen (websites 6 and 8); Stipagrostis shawii in Libya and Sudan (Boulos 2005); and Indigofera lotononoides in Sudan (Boulos 1999 and website 8).

The dominance of therophytes over the other life forms seems to be a response to the hot-dry climate, topographic variation and biotic influence (Heneidy and Bidak 2001). In Egypt, the highest humid period of the year extends from November to April which is associated with low temperature and evaporation; therefore, much favorable soil moisture. During this period, the plants start their growth activity reaching to the flowering and fruiting stages in March, April and May (Bedevian 1935, Makins et al. 1948, Boulos and Hadidi 1986, Griffiths 1992, Bircher 1998,
Burnie et al. 2004 and Heneidy 2010). Regarding the sex forms, the preponderance of the hermaphroditic taxa (i.e. bisexual taxa) is a common feature in most floras of the world. Baker and Hurd (1968) suggested that the coevolution of hermaphroditic flowers with animal pollination might be an important advancement by early angiosperms since pollen-producing and pollen-receiving organs in the same flower allowed for efficient simultaneous deposition and removal of pollen. Ballochores followed by pogonochores are the most represented dispersal types that characterized the near-endemic taxa in the Egyptian flora. The wide distribution of ballochoric taxa may be due to their explosive nature, which is often related to rapid desiccation, and hence efficient local seed dispersal.

Records of the present study indicate that the number of near-endemic taxa had the maximum value in Sinai especially its south, as it includes 50 near-endemics (68.5\%). On the other hand, near-endemics are poor in each of Red Sea coastal strip and deserts (2.7\%). Fifty-one steno-near endemics (69.9 \% out of 73 taxa) were recorded in the present study. Sinai includes the majority of steno-near endemics (33 taxa $=64.7 \%$ of total steno-near endemics), while Eastern Desert includes 3 species and Gebel Elba includes only one species. The richness of South Sinai region with near and steno-near endemics is probably due to the extensive mountainous massive in this region which prevents the dispersal of seeds for long distances. Regarding the rarity forms, there are many ways in which a species can become rare; a theoretical framework of an eight-celled table is proposed by Rabinowitz (1981) for the different types of rarity depending on range, habitat specificity and local abundance. In the present study, 70 nearendemics (94.6\% of the total near-endemics) belonged to SNN cell (constantly sparse and geographically restricted in a specific habitat); while, 4 near-endemics belonged to SNA cell (locally abundant in a specific habitat but restricted geographically). Taxa that belong to SNA and SNN are the classic rarities in the sense of restricted endemics, often endangered or threatened. Taxa which have large ranges, but are associated with particular habitats are 


\section{Re-assessment of the near-endemic taxa in the Egyptian Flora}

generally quite predictable in their occurrence; these taxa tend to be precarious as a result of habitat destruction (Rabinowitz 1981 and Ahmed 2009).

All of the near-endemics in the present study had at least one aspect of the potential or actual economic goods. Fifty-one nearendemics (69.9 \%) are of medicinal use. For example, the seeds and leaves of Ducrosia imaelis are used for treating stomach diseases, and has an antimicrobial activity (AlGhonemy 1993). Also, the whole herb, especially its aerial parts, has been used in traditional medicines to treat skin infections and to repel insects and reptiles. Cytotoxic homo-isoflavones, 8 new and 10 known compounds were isolated from the organic extract of the bulbs of Bellevalia eigii as part of a search for anticancer (Alali et al. 2015). Essential oil of Thymus bovei has anthelmintic, antibacterial and antioxidant effects (Jaradat et al. 2016). Seventeen near-endemics can be grazed and browsed by the domestic and wild animals (e.g. Phagnalon sinaicum, Picris sulphurea, Pterocephalus arabicus, Silene biappendiculata, Micromeria sinaica and Plantago sinaica). In addition, many organs (e.g. fruits, flowers, vegetative and ground parts) of 11 near-endemics are eaten by local inhabitants in different regions of Egypt. Among these plants are: Allium barthianum, Carthamus glaucus, Thymus bovei and Carduncellus mareoticus. Only one nearendemic was used as fuel (Lycium shweinfurthii var. aschersohnii). In addition, 20 near-endemics are of several traditional uses (such as: esthetic concerns, fodder, weaving and oil) (e.g. Pimpinella etabica, Medemia argun, Enarthrocarpus pterocarpus, Convolvulus schimperi).

Threats to the world's plants continue to increase as a result of human activities (IUCN 2003, 2010). Among the well-documented threats are habitat loss, poor land management, over-collection, overgrazing, and climate change. Most studies suggest that the rate at which plant species are being lost, or at least reduced in numbers, is faster than the speed at which scientists; land managers, policy-makers, and others can or will respond (IUCN 2003, 2010). All the nearendemic species suffer from at least one type of threats in their main habitats. All the nearendemics are subjected to over-cutting and over-collecting by local inhabitants, herbalists and scientific researchers. The most serious aspect of this practice is that it usually targets rare and localized flora leading to damage them further (Seif El-Nasr and Bidak 2005a). Twenty-six near-endemics are subjected to over-grazing where sheep and goats severely depleted the natural vegetation and compete directly with native wildlife over the same food resource (Seif El-Nasr and Bidak 2005a). Plantago sinaica is one of the over-grazed near-endemic species in South-Sinai (Khafagi et al. 2012). Twenty near-endemics are damaged during agriculture process, where a complete destruction of habitats caused by cultivation activities is a serious threat to many regions in Egypt, especially in the Mediterranean region (Seif El-Nasr and Bidak 2005a).

In addition, 25 near-endemics (e.g. Allium barthianum, Ferula marmarica, Belevallia eigii, Centurea alexandrina and Pterohagia arabica) are exposed to habitat loss due to urbanization and tourism, clearance for agriculture and construction processes. This is one of the major threats which impact many species, in the Egyptian flora especially in the Mediterranean region. This has not only led to the complete destruction of the habitats, but also its degradation of vast areas of habitat surrounding them. In addition, 15 nearendemics (e.g. Allium tel-avivens, Carduncellus mareoticus, Colchicum cornigerum) were damaged during mining and quarrying; one of the major processes causing degradation in the ecosystems of many Egyptian regions due to complete destruction of plant cover (Seif El-Nasr and Bidak 2005b). In general, the major effective threats are overcutting, over- collecting, and over-grazing which are dominant is North Sinai and Mediterranean; habitat loss, urbanization, tourism and clearance for agriculture which are abundant in the Mediterranean and Red Sea coasts as well as Sinai.

The present study provides an important material towards the conservation of nearendemic species in Egypt, especially stenoendemics and near-endemics. Using the IUCN red list criteria, 30 near-endemic taxa were 


\section{Shaltout et al.}

evaluated as follows: 12 endangered (40 \%), 5 critically endangered, 4 believed to be extinct, while only one is vulnerable. On the other hand, 8 taxa have no adequate information about their occurrence, so they were evaluated under category of data deficient. Most of the near-endemics are not evaluated due to the rarity of data about these species. Some previous studies were carried out for the assessment of near-endemic species according to IUCN categories. For example, Hosni et al. (2013) evaluated 61 near-endemics as follows: 17 vulnerable, 13 critically endangered, 10 endangered, 15 near- threatened, 5 regionally extinct and 1 least concern. El- Hadidi and Hosni (2000) evaluated 36 near-endemics as follows: 4 vulnerable, 16 endangered, 4 indeterminate, 1 extinct and 11 rare; while IUCN (1998) evaluated 9 near-endemics as follows: 2 endangered, 1 indeterminate and 6 rare; while Johnson (1998) and Ibrahim et al. (2008-2010) evaluated Medemia argun as critically endangered.

Two near-endemics were evaluated only in the present study as endangered species: Lotus nubicus $\left(\mathrm{EOO}=478.2 \mathrm{~km}^{2}, \mathrm{AOO}=78.0\right.$ $\mathrm{km}^{2}$ ) and Allium stamineum subsp. decaisnei $\left(\mathrm{EOO}=89.8 \mathrm{~km}^{2}, \mathrm{AOO}=26.1 \mathrm{~km}^{2}\right)$.

Two taxa were evaluated in the present study as well as the three previous studies. Scorzonera drarii evaluated as endangered by IUCN (1998) and El-Hadidi and Hosni (2000), but it was believed to be extinct in the present study and Hosni et al. (2013), because it was known only from its type locality or a single gathering (Hosni et al. 2013). In addition, Micromeria sinaica was evaluated as rare by IUCN (1998) and El-Hadidi and Hosni (2000) and vulnerable by Hosni et al. (2013), but as critically endangered in the present study $\left(\mathrm{EOO}=0.7 \mathrm{~km}^{2}, \mathrm{AOO}=2.2 \mathrm{~km}^{2}\right)$, as it is under the risk of extinction due to its low population size and restricted distribution (El-Hadidi et al. 1992).

Twelve taxa were evaluated in the present study as well as two previous studies. Of these, Isatis microcarpa var. blepharocarpus was evaluated as rare by ElHadidi and Hosni (2000) and vulnerable by Hosni et al. (2013), but as endangered in the present study $\left(\mathrm{EOO}=44.0 \mathrm{~km}^{2}, \mathrm{AOO}=10.3\right.$ $\mathrm{km}^{2}$ ); Phagnalon sinaicum was evaluated as rare by El-Hadidi and Hosni (2000), but as endangered by Hosni et al. (2013) and the present study $\left(\mathrm{EOO}=834.7 \mathrm{~km}^{2}, \mathrm{AOO}=249.0\right.$ $\mathrm{km}^{2}$ ). This species is under the risk of extinction due to its low population size and very limited geographical distribution (ElHadidi et al. 1992); Podonosoma galalensis was evaluated as indeterminate by El-Hadidi and Hosni (2000), but as critically endangered by Hosni et al. (2013) and the present study $\left(\mathrm{EOO}=2.9 \mathrm{~km}^{2}, \mathrm{AOO}=2.1 \mathrm{~km}^{2}\right) ;$ Verbascum letourneuxii was evaluated as vulnerable by Hosni et al. (2013), but as endangered by ElHadidi and Hosni (2000) and the present study $\left(\mathrm{EOO}=944.1 \mathrm{~km}^{2}\right.$, AOO $\left.=110.4 \mathrm{~km}^{2}\right)$; Allium barthianum was evaluated as rare by El-Hadidi and Hosni (2000) and as regionally extinct by Hosni et al. (2013), but as vulnerable in the present study $\left(\mathrm{EOO}=157.5 \mathrm{~km}^{2}, \mathrm{AOO}=975.5\right.$ $\mathrm{km}^{2}$ ). Habitat loss due to establishment of touristic settlements was the major threat which caused this taxon to be vulnerable (field observation); Iris mariae was evaluated as rare by El-Hadidi and Hosni (2000) and as regionally extinct by Hosni et al. (2013), but it is considered to be extinct in the present study. Iris mariae is unique to sand and stabilized sand, and does not stray from this habitat. This habitat is threatened by the agricultural and residential development plans. Iris mariae is sensitive to rodents that feed on its rhizomes and to intensive grazing. (https://redlist.parks.org.il/taxa/Iris\%20mariae /); Crepis libyca was evaluated as regionally extinct by Hosni et al. (2013) and as indeterminate by IUCN (1998), but it is considered to be extinct in the present study. On the other hand, 5 taxa (Haloxylon negevensis, Centaurium malzacianum, Hypecoum aequilobum, Thymus bovei and Reaumuria negevensis) were evaluated in the present study as data deficient due to inadequate information to make correct assessment based on its distribution and/or population status. The limited geographical region of Thymus bovei combined with overexploitation; over-collecting as flavor to food and over-grazing by domestic livestock were other threats leading to the species decline (ElHadidi et al. 1992).

Fourteen taxa were evaluated in the present study and only one previous study. Of 


\section{Re-assessment of the near-endemic taxa in the Egyptian Flora}

these, 11 taxa were evaluated in the present study and Hosni et al. (2013): Carduncellus mareoticus was evaluated as indeterminate in Hosni et al. (2013), but as critically endangered in the present study $(\mathrm{EOO}=0.6$ $\mathrm{km}^{2}$, AOO $=0.4 \mathrm{~km}^{2}$ ); Fagonia mollis var. hispida was evaluated as Least concern by Hosni et al. (2013), but as endangered in the present study $\left(\mathrm{EOO}=673.3 \mathrm{~km}^{2}, \mathrm{AOO}=207.9\right.$ $\mathrm{km}^{2}$ ); Ferula marmarica was evaluated as near-threatened by Hosni et al. (2013), but as critically endangered in the present study $\left(\mathrm{EOO}=5.9 \mathrm{~km}^{2}\right.$, AOO $\left.=1.4 \mathrm{~km}^{2}\right)$; Carthamus glaucus subsp. alexandrinum (EOO is $.1 \mathrm{~km}^{2}$, AOO is $22 \mathrm{~km}^{2}$ ) and Pycnocycla tomentosa $\left(\mathrm{EOO}=661.7 \mathrm{~km}^{2}\right.$, AOO $\left.=423.0 \mathrm{~km}^{2}\right)$ were evaluated as vulnerable by Hosni et al. (2013), but as endangered in the present study; Centaurea glomerata was evaluated as endangered by Hosni et al. (2013) and the present study $\left(\mathrm{EOO}=684.4 \mathrm{~km}^{2}, \mathrm{AOO}=482.4\right.$ $\left.\mathrm{km}^{2}\right)$; Minuratia picta var. sinaica was evaluated as vulnerable by Hosni et al. (2013), but as critically endangered in the present study $\left(\mathrm{EOO}=16.3 \mathrm{~km}^{2}\right.$, AOO $\left.=3.8 \mathrm{~km}^{2}\right)$; Plantago sinaica was evaluated as critically endangered by Hosni et al. (2013), but as endangered in the present study $(\mathrm{EOO}=945.3$ $\mathrm{km}^{2}$, AOO $=268 \mathrm{~km}^{2}$ ). Over-grazing and overcollecting were the major threats which cause this taxon to be endangered (Khafagi et al. 2012). On the other hand, 3 taxa (Silene biappendiculata var. biappendiculata, Herniaria cyrenaica and Nilgella arvensis var. beersherensis) were evaluated in the present study as data deficient due to inadequate information to make correct assessment based on their distribution and/or population status. In addition, 3 taxa were evaluated in the present study and El-Hadidi and Hosni (2000). Of these: Withania obtusifolia (EOO $=871.7$ $\mathrm{km}^{2}$, AOO $=304.2 \mathrm{~km}^{2}$ ) and Zygophyllum dumosum $\left(\mathrm{EOO}=146.5 \mathrm{~km}^{2}, \mathrm{AOO}=42 \mathrm{~km}^{2}\right)$ were evaluated as vulnerable by El-Hadidi and Hosni (2000), but as endangered in the present study. The small populations of Withania obtusifolia are highly endangered due to establishment of touristic settlements. Overcollection for medicinal uses is another reason for its decline (El-Hadidi et al. 1992). Overgrazing by camels highly disturb the small populations of Zygophyllum dumosum (El-
Hadidi et al. 1992); while Fagonia taeckholmiana was evaluated as extinct in the present study and El-Hadidi and Hosni (2000). It was known only from its type locality (Heliopolis desert, near Cairo). At present, this area is under heavy industrial activities due to the establishment of Nasr town (EL-Hdadidi et al. 1992).

Thirty-six near-endemic taxa were evaluated by the previous studies (Hosni et al. 2013, El-Hadidi and Hosni 2000 and IUCN 1998), but not in the present study. Among them, two taxa were evaluated by the three previous studies. Astragalus camelroum was evaluated as rare by Hosni et al. (2013) and IUCN (1998), but as endangered by El-Hadidi and Hosni (2000); while Pterocephalus arabicus was evaluated as critically endangered by Hosni et al. (2013), but as endangered by El-Hadidi and Hosni (2000) and rare by IUCN (1998). Tourism among some external factors may lead to gradual extinction of Pterocephalus arabicus (ElHadidi et al. 1992), its natural rarity can be related to its geographical distribution. Degradation of vegetation due to overgrazing was pronounced in wadis where their vegetation is relatively rich and dense. Complete destruction of the natural vegetation is carried out for settlements. Anthropogenic activities also have dramatic effect over natural vegetation especially in desert, where plant life subsits under adverse conditions of aridity (Abd El-Ghani and Fahmi 1994).

In addition, 14 taxa were evaluated by two previous studies. Of these, Allium crameri was evaluated as endangered by Hosni et al. (2013) and as rare by El-Hadidi and Hosni (2000); Lupinus digitatus and Valerianella pterovitchii were evaluated as endangered by Hosni et al. (2013) and El-Hadidi and Hosni (2000); Medemia argun was evaluated as endangered by El-Hadidi and Hosni (2000) and IUCN (1998). This plam was exposed to cut for collection of their edible fruits and using the leaves to make strong ropes (ELHadidi et al. 1992). The vegetation of this palm is influenced by human activity. The ecosystems are rare, to some extent even unique, vulnerable and critically endangered 


\section{Shaltout et al.}

that make protection necessary. The population size showed a dramatic decrease in the last decade. The total number of Medemia palms in Egypt was 31; with two fruiting females (Ibrahim et al. 2008-2010); Colchicum cornigerum was evaluated as vulnerable by Hosni et al. (2013), but as endangered by ElHadidi and Hosni (2000); Nonea vivanii was evaluated as vulnerable by Hosni et al. (2013), but as rare by IUCN (1998); Anabsis syriaca var. syriaca was evaluated as vulnerable by Hosni et al. (2013) and El-Hadidi and Hosni (2000). The rarity of Anabsis syriaca var. syriaca is due to its limited local distribution. Also, Agricultural activities and overgrazing are main factors leading to decline of this taxa (El-Hadidi et al. 1992); Convolvulus shimperi was evaluated as endangered by Hosni et al. (2013), but as rare by El-Hadidi and Hosni (2000); Ebenus armitagei, Lupinus palaestinus and Ducrosia ismaelis were evaluated as critically endangered by Hosni et al. (2013), but as endangered by El-Hadidi and Hosni (2000). It was found that $94 \%$ of the seeds of the rare legume Ebenus armitagei were eaten or damaged by bruchid beetles Callosobruchus maculatus (Hegazy and Isa 1991); this species also was only recorded from the Mediterranean sector of Egypt. The pods and seeds are severly attacked by insects which threaten plant reproduction. Also, most of the natural vegetation in the Mediterranean region had been much disturbed by clearing for establishment of new touristic settlements (EL-Hadidi et al.1992); Pimpinella etabica and Verbascum fruticulosum were evaluated as critically endangered by Hosni et al. (2013), but as rare by El-Hadidi and Hosni (2000). Overgrazing and rarity of water are main factors which affect the regeneration of Verbascum fruticulosum (El-Hadidi et al. 1992); while Origanum isthmicum was evaluated as endangered by El-Hadidi and Hosni (2000), but as rare by IUCN (1998).

Twenty taxa were evaluated by only one previous study. Of these, 5 taxa were evaluated by El-Hadidi and Hosni (2000): Bellevalia eigii, Biarum oliveri, Delphinium bovei and
Helianthemum sphaerocalyx were evaluated as endangered. The habitat of Biarum oliveri is sandy soil which is easily disturbed by mechanical means and the surface is easily damaged, destroying Biarum olivieri. Intensive grazing is also destructive (https://redlist.parks.org.il/taxa/Biarum\%20oli vieri/). Helianthemum sphaerocalyx was severely threatened by tourism, human settlement and extraction of oil (IUCN 1978); while Kickxia macilenta was evaluated as rare. The natural rarity of the Kickxia macilenta can be related to its geographical distribution. Degradation of vegetation due to overgrazing is pronounced in wadis where its vegetation is relatively rich and dense. Complete destruction of the natural vegetation is carried out for settlements. Anthropogenic activities also have dramatic effect over natural vegetation especially in desert, where plant life subsits under adverse conditions of aridity (Abd ElGhani and Fahmy 1994). In addition, the extreme rarity of this taxon is related to its limited geographical distribution. The mountains of S. Sinai act as refuges that harbor the small population of this taxon (El-Hadidi et al. 1992).

Only one taxon (Atractylis boulosii) was evaluated as rare by IUCN (1998). In addition, 14 taxa were evaluated by Hosni et al. (2013): of these 5 taxa were evaluated as vulnerable (Kickxia floribunda, Astragalus amalcitanus, Linaria joppensis, Lycium schweinfurthii var. aschersohnii and Pterohagia arabica); 5 taxa as critically endangered (Enartherocarpus pterocarpus, Bupleurum nanum, Convolvulus spicatus, Nigella deserti and Trifolium philistaeum); three taxa as endangered (Leopoldia eburnean, Leopoldia longipes subsp. negevensis and Haplophyllum poorei); while only one taxon (Hypecoum aegyptiacum) as least concern. Hypecoum aegyptiacum apparently disappeared from the sites where it had been previously found and there is doubt as to its existence today. There is no information on the past populations nor are the reasons for its disappearance from the sites where it had been collected in the past clear. There is also a lack of information regarding its global threat status (Shimda and Pollak 2007). 


\section{Re-assessment of the near-endemic taxa in the Egyptian Flora}

\section{References}

Abd El-Ghani $M$ and Fahmy A (1994).

Studies on the Threatened Woody Perennial Taxa in the Flora of Egypt II. Extinct and endemic taxa. Journal of Botanical Taxonomy and Geobotany 105 (3-4): 243-250.

Ahmed D (2009). Current Situation of the Flora and Vegetation of the Western Mediterranean Desert of Egypt. Ph.D. Thesis, Tanta University, Tanta. pp. 424.

Alali F, El-Elimat T, Albataineh H, Al-Balas Q, Al-Gharaibeh M, Falkinham JO, Chen WL, Swanson SM and Oberlies NH (2015). Cytotoxic Homo-isoflavones from the Bulbs of Bellevalia Eigii. US National Library of Medicine, National Institutes of Health. J. Nat. Prod. 78(7):1708-1715.

Al-Ghonemy A (1993). Encyclopedia of Medicinal Plants of the United Arab Emirates. University of United Arab Emirates. pp 568.

Al-Rawi A (1987). Flora of Kuwait: Volume 2 (Monocotyledoneae and Compositae). Alden Press Ltd, Oxford. pp 455.

Al-Yahya A, El-Meshal I, Mossa J, Al-Badr $A$ and Tarik M (1990). Saudi plants. A Phytochemical and Biological Approach. General Directorate of Research Grants Programs, King Abdul Aziz City for Science \& Technology, Riyadh. pp 524.

Andesron S (1994). Area and Endemism. Quarterly Review of Biology 69: 151- 471.

Andrews F (1950-1956). The Flowering Plants of the Sudan. Vols. 1-3. Arbroath, Scotland.

Baker $H$ and Hurd $P$ (1968). Intra-Floral Ecology. Annual Review 13 : 385 - 414.

Batanouny K (1981). Ecology and Fora of Qatar. Alden Press ltd, Oxford. pp 245.

Bedevian AK (1935). Illustrated Polyglottic Dictionary of Plant Names. Madbouly Bookshop, Cairo. pp. 643.

Bircher W (1998). Delchevalerie" Les Plantes Exotiques Cultivées en Égypte" an Updated English Version. Taeckholmia,18 (2): 1-111.

Boulos L and El-Hadidi N (1986). The Street Trees of Egypt. The American University in Cairo Press 113, Cairo, Egypt. pp. 108.

Boulos L (1999-2005). Flora of Egypt: Volumes 1-4. Al-Hadara Publishing, Cairo.

Boulos L (2009). Flora of Egypt Checklist, Revised Annotated Edition. Al- Hadara publishing, Cairo. PP. 410.
Burnie G, Forrester S, Guest S, Harmony $M$, Lavarack P, Letgett $M$, McDonald R, Macoboy S, Molyneux B, Moodie D, Moore J, Newman D, North T, Piennaar K, Purdy G, Silk J, Ryan S and Schien G (2004). Botanica, Ullmann Press, China, pp. 1020.

Butchart S, Stattersfield A, Bennun L, Shutes S, Akcakaya H, Baillie J, Stuart S, Hilton-Taylor C and Mace G (2004). Measuring Global Trends in the Status of Biodiversity: Red List Indices for Birds. Plos Biology 2(12): 383.

Collar N (1993-1994). Red Data Books, Action Plans, and the Need for Site-specific Synthesis. Species 21, 22: 132-133.

Collar N (1996). The Reasons for Red Data Books. Oryx. 30:121-130.

Collenette S (1985). Flowers of Saudi Arabia. Scorpion Publishing LTP. London. pp 514.

Collenette S (1999). Flowers of Saudi Arabia. National Commission Wild Life Conservation and Development, Riyadh. pp 800.

Cunningham $\mathbf{W}$ and Cunningham $\mathbf{M}$ (1997). Environmental Science, Inquiry and Applications. $3^{\text {rd }}$. ed. Mc Gram Hill Higher Education, NewYork, USA.

Dansereau $P$ and Lems $K$ (1957). The Grading of Dispersal Types in Plant Communities and their Ecological Significance. Institut Botanique de L'Universitè de Montrèal, Montrèal 71: 1-52. Davis P et al. (eds.) (1972-1982). Flora of Turkey and the East Aegean Islands. Vols 2, 4, 6, 7. Edinburgh.

El- Hadidi M, Abd El- Ghani M and Fahmy A (1992). The Plant Red Data Book of Egypt, 1. Woody Perennials. Palm Press and Cairo University Herbarium. pp 154.

El-Hadidi $M$ and Hosni $H$ (2000). Conservation and Threats: in M. N. El-Hadidi (ed.) Flora Aegyptiaca vol. 1(1), Palm Press. Cairo. pp. 105-180.

El- Shabasy A (2016). Survey on Medicinal Plants in the Flora of Jizan Region, Saudi Arabia. International Journal of Botany Studies 2: 38-59. 
Feinbrun-Dothan N (1978). Flora Palaestina, Part Three, Israel Academy of Science and Humanities, Jerusalem. pp 481.

Feinbrun-Dothan $\quad \mathbf{N}$ (1986). Flora Palaestina, Part Four, Israel Academy of Science and Humanities, Jerusalem. pp 462.

Gaston K (1994). Rarity. - London: Chapman \& Hall.

Griffiths, M. (1992). The New Royal Horticultural Society Dictionary of Gardening, Publisher Macmillan, UK, Four volumes, pp. 3239.

Haston E, Richardson J, Stevens P Chase M and Harris $D$ (2009). The Linear Angiosperm Phylogeny Group (LAPG) III: A linear Sequence of the Families in APG III. Biological Journal of Linnean Society 161: 128-131.

Hegazy $A$ and Eesa $N$ (1991). On the Ecology, Insect Seed-Predation, and Conservation of a Rare and Endemic Plant Species: Ebenus armitagei (Leguminosae). Conservation Biology 5 (3): 317-324.

Heneidy S and Bidak L (2001). Multipurpose Plant Species in Bisha, Asir Region, South Western Saudi Arabia. Journal of King Saud University 13 (Science: 1 \& 2): 11 - 26.

Heneidy S (2010). Plant Altas "The Botanic Garden (Alex)". Faculty of Science, Alexandria University, Monsha'a Al Maaref, Alexandria, Egypt, pp. 632.

Hosni H, Hosny A, Shamso E and Hamdy R (2013). Endemic and Near-endemic Taxa in the Flora of Egypt. Egyptian Journal of Botany 53:357-383.

Ibrahim K, Hosni H and Pterson P (2016). Grasses of Egypt. Smithsonian contributions to Botany 103:1-201.

Ibrahim H, Noby $K$, Ezat M, Ebaid A, Hassan A, Saied W, Abd Elazim S and Mekki H (2008-2010). Conservation of Medemia argun and Nubian Desert Oases Biodiversity in Egypt, Final Report. Conservation Leader Ship Programme, CLP. IUCN (1978). The IUCN Plant Red Data Book. International Union for Conservation of Nature and Natural Resources, Hugh Synge International Union for Conservation of Nature and Natural Resources Threatened Plants Committee. pp 540.

IUCN (1994). IUCN Red List Categories and criteria version 2.3. Prepared by the Species
Survival Commission. IUCN, Gland, Switzland.

IUCN (1998). IUCN Red List of Threatened Plants. (Walter K and Gillett J eds.). IUCN, Gland, Switzerland \& Cambridge, The World Conservation Union. pp 862.

IUCN (2001). IUCN Red Data List Categories and Criteria. Version 3.1. IUCN, Gland, Switzerland and Cambridge, UK.

IUCN (2003). Guidelines for Application of IUCN Red List Criteria at Regional Levels: Version 3.0. IUCN Species Survival Commission. - IUCN, Gland, Switzerland \&Cambridge, UK.

IUCN (2010). Standards and Petitions Subcommittee. 2010. Guidelines for using the IUCN Red List Categories and Criteria. Version 8.1. Prepared by the Standards and Petitions Subcommittee in March 2010.

Jafri S and El-Gadi A (1977 -1988). Flora of Libya. Al- Faateh University, Faculty of Science, Department of Botany and National Academy for Scientific Research (N.A.S.R), Tripoli.

Jaradat N, Adwan L, K'aibni S, Shraim N and Zaid AN (2016). Chemical Composition, Anthelmintic, Antibacterial and Antioxidant Effects of Thymus bovei Essential Oil. US National Library of Medicine, National Institutes of Health. BMC complement altern med. 16(1):418.

Jetz W and Freckleton RP (2015). Towards A General Framework for Predicting Threat Status of Data-deficient Species from Phylogenetic, Spatial and Environmental Information. Philosophical transactions of the Royal Society of London. Series B, Biological Science.

Johnson D (1998). Medemia argun. The IUCN Red List of Threatened Species 1998.

Khafagi O, Hatab E and Omar K (2012). Challenges Towards Hypericum sinaicum Conservation in South Sinai, Egypt. Jordan Journal of Biological Sciences, 6 (2): 117 126.

Mace G, Collar N, Gaston K, Hilton- Taylor C, Akcakaya H, Leader-Williams $\mathbf{N}$, Milner- Gulland E and Stuart S (2008). Quantification of Extinction Risk: IUCN's System for Classifying Threatened Species. Conservation Biology 22: 1424-1442. 


\section{Re-assessment of the near-endemic taxa in the Egyptian Flora}

Maes D, Isaac N, Harrower C, Collen B, Strien A and Roy D (2015). The Use of Opportunistic Data for IUCN Red List Assessments. Biological Journal of Linnaean Society, 115.Pages

Makins FK, Makins MA and Makins FL (1948), The Identification of Trees and Shrubs. J. M. Dent and Son LTD, Aldine House, Bedford. pp. 375.

Mansour H, Jimenez A, Keller B, Nowak M and Conti E (2013). Development of 13 Microsatellite Markers in the Endangered Sinai Primrose (Primula boveana). Applications in Plant Sciences; 1 (6): 1-3

Migahid A (1988). Flora of Saudi Arabia, vol. One, $3^{\text {rd }}$ ed., King Saud University Libraries, Riyadh. PP 251.

Migahid A (1989). Flora of Saudi Arabia, vol. Two, $3^{\text {rd }}$. ed., King Saud University Libraries, Riyadh. PP 282.

Migahid A (1990). Flora of Saudi Arabia, vol. Three, $3^{\text {rd }}$. ed., King Saud University Libraries, Riyadh. PP 150.

Omar K (2014). Primula boveana. The IUCN Red List of Threatened Species 2014.

Omar K (2015-2016). Ecological and Conservation Assessment of Rosa arabica in St Katherine-Egypt, Final Report. Conservation Leadership Programme, Birdlife International, Fauna \& Flora International and Wildlife Conservation Society.

Omar K (2017). Anarrhinum pubescens. The IUCN Red List of Threatened Species 2017.

Omar K (2017). Bufonia multiceps. The IUCN Red List of Threatened Species 2017.

Omar K (2017). Phlomis aurea. The IUCN Red List of Threatened Species 2017.

Omar K (2017). Rosa arabica. The IUCN Red List of Threatened Species 2017

Rabinowitz D (1981). Seven Forms of Rarity. In Synge, H. (ed.): The Biological Aspects of Rare Plant Conservation, John Wiley \& Sons Ltd, London. pp. 205 - 217.

Raunkiaer C (1937). Plant Life Forms. Clarendon, Oxford. pp. 104.

Seif El-Nasr M and Bidak L (eds.) (2005a). Conservation and Sustainable Use of
Medicinal Plants Project: National Survey, North Western Coastal Region. First Quarterly Report. Mubarak City for Scientific Research and Technology Applications. pp. 178.

Seif El-Nasr M and Bidak L (eds.) (2005b). Conservation and sustainable Use of Medicinal Plants Project: National Survey, Northwestern Coastal Region. Third Quarterly Report. Mubarak City for Scientific Research and Technology Applications. pp. 57

Shaltout K, Sharaf El-Din A and Ahmed D (2010). Plant Life in the Nile Delta. Tanta Univ. Press, Tanta, Egypt. pp.231.

Shimda A and Pollak G (2007). Red Data

Book: Endangered Plants of Israel. The

Hebrew University Manes Press.

Täckholm V (1956). Students' Flora of Egypt. Anglo-Egyption Bookshop, Cairo. pp. 649.

Täckholm V (1974). Students' Flora of Egypt: $2^{\text {nd }}$ ed. Cairo University. pp. 888.

Täckholm V and Drar M (1950). Flora of Egypt: Volume II, Bull. Fac. Sci., Fuoad I Univ. no. 28: 1-547.

Täckholm V and Drar M (1969). Flora of Egypt: volume VI, Bull. Fac. Sci., Cairo Univ. 1-. 427.

Täckholm G, Täckholm V and Drar, M (1941). Flora of Egypt: Volume I, Bull. Fac. Sci., Fuoad I Univ.no.17: 1-574.

Taifour H and El-Oqlah A (2014). Jordan Plant Red List. Royal Botanic Garden, Jordan. pp. 1289.

Thomas, C, Cameron A, Green R, Bakkenes M, Beaumount L, Collingham Y, Erasmus B, Grainger A, Ortega-Huerta M, Petrson A, Phillips $O$ and Williams S (2004). Extinction Risk from Climatic Change. Nature 427: 145-148.

Townsend $C$ and Guest $E$ (eds.) (1966-1980). Flora of Iraq, Vols. 1-4, Ministry of Agriculture. Baghdad.

Wickens G (1992). Arid and Semiarid Ecosystems in Encyclopedia of Earth System Science 1, 113-118 - England: Academic Press Inc. 


\section{Shaltout et al.}

Zaghloul M, Hamrick J, Moustafa A, Kamel W and El-Ghareeb R (2006). Genetic Diversity Within and Aamong Sinai Populations of Three Ballota species (Lamiaceae). Journal of Heredity 97 (1): 6454.

Zahran $M$ and Willis A (2009). The Vegetation of Egypt, $2^{\text {nd }}$ ed. Springer. pp. 437.

Zohary M (1966-1987). Flora Palaestina, Parts One and Two. Israel Academy of Science and Humanities. Jerusalem.

\section{Websites}

1- (http://www.ipni.org).

2- (http://www.theplantlist.org).

3- (http://www.plantsoftheworldonline.org).

4- (http://www.catalogueoflife.org/annualchecklist/2010).

5- (http://www.tropicos.prg/Home.aspx).

6- (http://www.gbif.org/occurence).

7-

(http://www.villege.ch/musinfo/bd/cjb/africa).
8- (http://plants.jstore.org).

9- (http://www.geocat.Kew.org).

10- (http://www.iucnredlist.org).11- (http// www. maps. com).

$12-$

(https://redlist.parks.org.il/taxa/Biarum\%20oli vieri/).13-

(https://redlist.parks.org.il/taxa/Iris\%20mariae /).

$14-$

(http://ww2.bgbm.org/EuroPlusMed/query.as p).

15- (http://wcsp.science.kew.org).

16- (http://epic.kew.org).

17- (http://www.plantdiversityofsaudiarabia).

18- (http://ww2.odu.edu).

19- (http://e-monocot.org).

20- (http://www.cfh.ac.cn).

21- (http://data.rbge.org.uk). 